\title{
Fiscal Incentives for Conflict: Evidence from India's Red Corridor*
}

\author{
Jacob N. Shapiro ${ }^{\dagger} \quad$ Oliver Vanden Eynde ${ }^{\ddagger}$
}

December 9, 2020

\begin{abstract}
Can tax regimes shape the incentives to engage in armed conflict? Indian mining royalties benefit the States, but are set by the central government. India's Maoist belt is mineral-rich, and States are responsible for counterinsurgency operations. We exploit the introduction of a $10 \%$ ad valorem tax on iron ore that increased royalty collections of the affected states by a factor of 10. We find that the royalty hike was followed by a significant intensification of violence in districts with important iron ore deposits. The royalty increase was also followed by an increase in illegal mining activity in iron mines.
\end{abstract}

Keywords: Counterinsurgency, Civil Conflict, Natural Resources

JEL Classification: D72, D74, L23

\footnotetext{
*This research was supported by ANR grant COOPCONFLICT, AFOSR grant \#FA9550-09-1-0314, ONR grant \#N00014-14-1-0843, EUR grant ANR-17-EURE-0001, Cepremap, and the International Growth Center. We would like to thank Eli Berman, Thiemo Fetzer, Jamie Hansen-Lewis, Ethan Kapstein, Patrick Kuhn, Eoin McGuirk, Cyrus Samii, Chris Woodruff, and Austin Wright. This paper also benefited from discussions with seminar participants at Columbia, Princeton, PSE, ESOC, PACDEV, EUDN, NYU Abu Dhabi, NBER, and NEUDC. This paper is a thoroughly revised version of an earlier draft entitled "Mining Royalties and Incentives for Security Operations". Tommaso D'Amelio, Jamie Hansen-Lewis, Sumit Parashar, and Shrenik Sanghvi provided excellent research assistance. Any errors remain our own.

${ }^{\dagger}$ School of Public and International Affairs, Princeton University. Email: jns@princeton.edu.

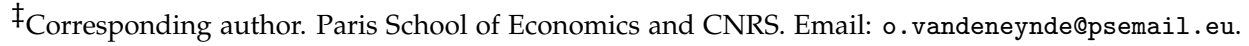




\section{Introduction}

Generating tax revenue is a core state capability. Fiscal policy could have important implications for the cost of fighting insurgencies and the prize of "winning" violent contest. However, the public finance of civil conflict has received little attention so far. Theories of civil conflict often assume a weakly institutionalized environment, in which rebels and states fight over abstract prizes. The reality of conflict is often one in which complex institutions and policies constrain the behavior of the state and shape the prize of the contest. These constraints are particularly relevant in decentralized countries, where successful counterinsurgency requires support from different levels of government. This paper studies the impact of a tax regime that strongly increased the value of controlling territory for sub-national governments.

Our paper exploits the introduction of a $10 \%$ ad valorem tax on the price of iron ore in India. This royalty regime was set by the central government, but its benefits accrued entirely to the states. Earlier, states received a negligible rate per tonne of iron ore mined within their boundaries. When the national government, or "Centre", introduced a $10 \%$ ad valorem tax in August 2009, the new royalty regime led to a 10-fold increase in the royalty collections of the affected states by 2011 . The new iron ore royalties contributed up to $5 \%$ of the state budgets. Among the beneficiaries of the royalty increase were states in India's "Red Corridor" - the region in the Center-East of the country that is affected by a long-standing conflict between Maoist insurgents and the state. As state governments are fully responsible for managing counter-insurgency efforts within their territory, the royalty hike could have affected their incentives to allocate efforts in iron-rich districts. ${ }^{1}$

Our empirical analysis shows that this royalty change for iron ore was followed by an increase in the extent and intensity of Maoist violence in districts with important iron ore deposits compared to other districts. Instead, coal and bauxite deposits are not associated with robust increases in violence. Like iron ore, these two minerals occur in

\footnotetext{
${ }^{1}$ The combination of centrally imposed tax rates and states that are responsible for managing conflicts in their boundaries (while facing the same rebel group) makes India well suited to study the role of fiscal incentives for conflict.
} 
many districts and are economically important, but they did not experience a comparable royalty hike. Importantly, royalty revenues are collected at the state-level and are not mechanically linked to the funding of local security operations. Therefore, the observed intensification of violence in iron ore districts is likely to reflect stronger incentives to control these zones.

A key characteristic of India's Maoist belt is that illegal mining is pervasive, and we expect these activities to be influenced as well by the royalty hike. It is well documented that state-level officials benefit from the rents created by this illegal sector (see e.g. Asher and Novosad, 2020). Illegal mining takes the form of mines that are larger than permitted or mines that are still in operation after their lease has expired. We construct proxy measures of such illegal mining activity based on satellite imagery. We find that the royalty hike was associated with increased illegal mining activity at iron mines compared to other mines.

We expect the royalty hike to affect the incentives of actors to engage in conflict and illegal mining through two mechanisms. One possibility is that state governments engage in conflict to secure mining sites. Thus, they benefit more from permitting illegal mining thanks to their improved bargaining positions. A second possibility is that mining firms increase the funding of Maoist rebels to shield their illegal activities, as these became more valuable after the royalty hike.

Our results speak to the literature exploring how the presence of natural resources and variation in their value affect conflict. With respect to presence, Lei and Michaels (2014) find that discoveries of oil fields increase the likelihood of conflict onset. There is conflicting evidence when it comes to value: Brückner and Ciccone (2010) find that commodity price slumps increase the onset of civil war in Sub-Saharan Africa at the country level; Berman et al. (2017) find that price shocks boost violence in the same region using grid-cell level data; and Bazzi and Blattman (2014) find no relationship between commodity prices and the onset of conflict in a cross-country panel, but do observe that rising prices tend to shorten wars. Potentially reconciling these findings, theoretical work by Dal Bó and Dal Bó (2011) argues that the sign of the relationship between commodity price shocks and conflict depends on whether the shock hits a 
capital-intensive or labor-intensive industry. In an empirical test of this hypothesis, Dube and Vargas (2013) show how increased coffee prices reduce violence, whereas increased oil prices boost violence. They argue that the relative capital intensity of oil versus coffee explains why the opportunity versus rapacity effects dominate respectively. In related work, Fetzer and Kyburz (2019) show how political power-sharing institutions in Nigeria mitigate resource conflict. The price shocks studied in the literature could be working either through an increase in government revenue (because of the price increases) or through an increase in overall activity in the sector. Our contribution is to focus on the impact of a shock that directly affects the government's returns to mining activity and show that the impact is unlikely to run only through the revenue channel.

Our results also contribute to an emerging literature that links taxation and conflict. Sánchez de la Sierra (2020), links mineral booms for different types of minerals to patterns in public good provision and taxation by rebels in the DRC. In Colombia, a setting with more established political institutions, Ch et al. (2018) show that violent actors shape tax regimes at the municipal level. ${ }^{2}$ Rather than focusing on how violent groups contribute to taxation, we highlight how the fiscal regimes that support political institutions shape the incentives of state actors to engage in conflict. The closest paper theoretically is Berman and Matanock (2015), who argue that potential tax revenues motivate governments to capture territory. They support this claim with evidence that increased private investment in the Philippines boosted both government and rebel violence. Christensen et al. (2019) show that Myanmar's military used more violence in areas that were rich in jade as part of a strategy of limiting the new civilian government's ability to control those resources. In a close paper to ours, Romero and Saavedra (2019) show that a reduction in the royalty rate flowing to local governments in Colombia boosted illegal mining, as local governments had less incentives to curb tax evasion. These authors also use satellite imagery to measure illegal mining. However, we find that a royalty hike boosts illegal mining in the context of India's Maoist conflict, and we

\footnotetext{
${ }^{2}$ Dube and Vargas (2013) suggest that the decentralization of oil revenues made it easier for rebels to control rents in Colombian municipalities. Given the larger size of Indian states, the decentralization of revenues at the state-level is unlikely to have boosted Maoist violence through this channel.
} 
link the royalty change to violence outcomes.

Our paper is organized as follows. First, we describe India's royalty regime. Second, we provide background on the Maoist conflict. Third, we introduce the data set. Fourth, we present the empirical strategy and the results. We conclude with an additional interpretation.

\section{Mining royalties in India}

India ranks among the world's top producers of iron ore, bauxite, and coal. In India's federal structure, the management of mineral resources is a shared responsibility between the central government of India and the state governments, as prescribed by the Mines and Minerals Development and Regulation [MMDR] Act 1957. The Centre sets the royalty rates on mineral output. While the state governments are the legal owners of all major mineral resources, their ability to profit from mining activity is severely restricted by the fact that they cannot set royalty rates. They do have the legal power to grant licenses, but the licenses in themselves cannot be sold. ${ }^{3}$ Hence, royalties are the main sources of direct, legal revenue from mining activity for State Governments, but they are externally imposed.

The MMDR 1957 allows the Centre to change royalty rates every three years. The 2009 round of royalty revisions is of particular interest. Most major minerals saw a marginal increase in royalty rates, but iron ore royalties increased substantially. Before 2009 , iron royalties were levied per metric tonne, at a rate of 27 Rs (approximately 0.05 USD). The August 2009 revisions introduced a 10\% ad valorem tax on iron ore, which led to an immediate 5-fold increase in the per unit royalty rate (to $150 \mathrm{Rs} /$ tonne) at fixed prices. Combined with price increases from late 2009 onward, royalty collections on iron increased by a factor of more than 10 in the affected states. ${ }^{4}$ By the 2010-11 budget year,

\footnotetext{
${ }^{3}$ Reconnaissance Permits, Prospect Licenses, and Mining Leases are attributed to the first applicant (http://mines.nic.in/faq.html, accessed December 2013). Application fees are negligible and set by the Centre.

${ }^{4}$ TableA1 of the online appendix provides sources.
} 
iron royalties accounted for almost $1 \%$ of GDP in certain states. Overall iron output did not increase substantially in 2009, as Figure A2 shows. ${ }^{5}$ Bauxite experienced a much smaller change in royalty rates in 2009 , from $0.4 \%$ to $0.5 \%$ of the international aluminum price (at the London Metal Exchange). ${ }^{6}$ Coal royalty rates did not increase until April 2012.

The earliest rumors of a royalty hike can be traced back to September 2007 when a Ministry of Mines study group recommended switching to such a regime. This report was an internal recommendation and the intention of the Government was still unclear at that point in time. The risk of inflation is cited as one of the reasons why the Government delayed the implementation of the proposal. ${ }^{7}$ The Government's plans to change its royalty policies took clear shape in January 2009, when substantially higher royalties were introduced for uranium. The Government stated that "royalty rates for other minerals would also be revised soon". ${ }^{8}$ We consider the announced intention to overhaul the royalty rates as the starting point of our treatment. After the 2009 elections in May (which, as anticipated, kept the existing coalition in power), the Ministry of Mines announced the $10 \%$ ad valorem royalty rate in June. ${ }^{9}$ The cabinet formally approved the new royalty regime on 12 August 2009 and its implementation was immediate. It is plausible that state governments and mining firms became increasingly certain of the imminent overhaul of the system from early 2009 onward, which is why we consider this as the start of our treatment. ${ }^{10}$

The argument in favor of a royalty hike and the new ad valorem system focused on

\footnotetext{
${ }^{5}$ After 2012, Indian iron ore output decreases sharply because of a temporary mining ban in Goa and Karnataka following the discovery of illegal mining scams. These states are not Maoist-affected nor part of our sample.

${ }^{6}$ Mineral Royalties, Government of India Ministry of Mines, January 2011, https://ibm.gov.in/ writereaddata/files/06302014174344mineralroyalties2011.pdf. Manganese and chromite rates went up respectively from $3 \%$ to $4.2 \%$ and from $7.5 \%$ to $10 \%$.

${ }^{7}$ Economic Times, 06/01/2008, https://tinyurl. com/y61djrc6.

${ }^{8}$ The Indian Express, 01/03/2009, https://tinyurl.com/y4zql3t3.

${ }^{9}$ Indian Express, 06/23/2009, https ://tinyurl . com/y5f53byw.

${ }^{10}$ Table A15 shows the robustness of our results to shifting the treatment to the implementation period.
} 
the need for "fair compensation" of States, as strong demand for iron ore in China had created windfall revenues for miners. The example of other iron-rich countries relying on ad valorem taxes (e.g. Australia and Brazil) also played a role. ${ }^{11}$ In addition, the press release invokes an efficiency argument: ad valorem taxes limit the need for future changes in royalty rates. ${ }^{12}$. Press reports on the new royalty regime do not mention the Naxalite conflict. Also, the law did not exclusively affect conflict zones, as major iron-rich states like Goa and Karnataka are not significantly affected by Maoist violence.

\section{India's Maoist Conflict and Mining}

India's Maoist (or Naxalite) conflict can be traced back to a peasant uprising that originated from West-Bengal in the 1960s. The sympathizers of the uprising founded a communist group that promoted armed struggle against the state. Between 1970 and 2000, different Naxalite groups challenged each other and the Indian states. However, 2004 saw a major break when the two main Naxalite outlets joined forces in the Communist Party of India (Maoist), or CPI (Maoist) (Kujur, 2009). The present-day CPI (Maoist) retains a commitment to armed struggle against the Indian state, while opposing participation in democratic elections. The 2004 merger was followed by a marked intensification of the conflict. In 2006, the Naxalite movement was described by the Indian Prime Minister Manmohan Singh as "the single biggest internal security challenge ever faced by our country". ${ }^{13}$. Between 2007 and 2013, the conflict claimed more than 5,000 lives. The continuing popularity and strength of the Naxalite movement is perceived to stem from chronic underdevelopment in the affected communities. ${ }^{14}$

\footnotetext{
${ }^{11}$ Ministry of Mines, "Report of the study group to review the rates of royalty and dead rent", $09 / 28 / 2007$.

${ }^{12}$ Ministry of Mines, No. 3/1/2005-MVI, 08/17/2009

${ }^{13}$ The Economist, "India's deadly Maoists", 07/26/2006.

${ }^{14}$ Ghatak and Vanden Eynde (2017) review the empirical work on India's Maoist conflict. Vanden Eynde (2018) shows that mining resources shape the response of the Maoists to rural income shocks. Fetzer (2020) finds that India's rural work programme MNREGA mitigates the effect of these rural income shocks on conflict, even if Khanna and Zimmermann (2017) argue that MNREGA initially increased violence due to
} 
Observers have pointed out the links between the Maoist movement and the mining industry. In 2010, the Maharashtra State Home Minister openly accused the mining industry of funding Maoist groups. ${ }^{15}$ His statements reflect a widespread belief that Naxalites benefit from mining revenues through extortion and the facilitation of illegal mining activity. In this context, illegal mining typically entails violations of environmental regulations. Miners can operate outside of the area for which a company had received environmental clearance ("excess mining"), or they can continue operations after the expiration of their lease. Miners are reported to pay protection money to the Maoists as well as bribes to the police and other government officials in order to conduct their illegal business. ${ }^{16}$ The simultaneous involvement of government officials and Maoists raises the possibility that Maoist activity is tolerated in order to shield illegal mines from unwanted attention. ${ }^{17}$ Such a Maoist-State nexus was explicitly put forward by Orissa's BJP leader in 2010. ${ }^{18}$ Even if there was no explicit tolerance of Maoist activities, there are reasons to believe that state governments did not fully internalize the economic disruption caused by Maoist violence. ${ }^{19}$ National government officials regularly accuse states of being "lax" in their approach towards Maoism. In 2014, the outgoing chief of the Central Reserve Police Force, a centrally funded force that assists the State Police, accused "some states" of "wanting Maoists to continue". ${ }^{20}$

In this context, we expect an increase in mining royalties to boost conflict through two main channels. First, investments in security operations should be complementary to the Maoists' attempts to disrupt the programme.

${ }^{15}$ SATP, 05/20/2010. See also Srivastava (2009).

${ }^{16}$ Times of India, 01/13/2013, https://tinyurl.com/y48mo47g. In general, the link between mining activity and political corruption is well-established. Asher and Novosad (2020) show that mining booms boost the election chances of criminal politicians and increase wealth accumulation of elected politicians.

${ }^{17}$ These claims extend specifically to iron ore mining (The Indian Wire, 05/08/2017, https://tinyurl. com/y2grxhkm).

${ }^{18}$ Indian Express, 01/14/2010, https://tinyurl.com/y47t9h3g; Hundistan Times, 11/24/2013 (https://tinyurl.com/y64ztcfk).

${ }^{19}$ For examples of such disruption see The Telegraph, 05/21/2009, https://tinyurl.com/y4udzdsb and Kujur (2009).

${ }^{20}$ Times of India, 11/28/2014 (https://tinyurl. com/yysdpff7). 
the royalty revenues from mining activity. Higher royalties raise the state governments' returns to controlling territory and we expect to see more state-led security operations. Even if the state bargains with mine owners to share rents from illegal mining activity, the boost in legal revenues will improve the state's bargaining position. As a result, the state could actually increase its support for illegal mining activity, as it benefits from the associated bribes. ${ }^{21}$ Second, for mine owners, higher royalty rates increase the value of illegal mining over legal mining (if illegal mining allows them to evade the royalties). In response to higher royalties, mine owners could simultaneously expand their illegal operations and boost the funding of Maoist groups to shield these activities (in line with the evidence described above).

\section{Data}

This paper combines data on conflict with administrative and remote-sensing derived data on mining. Our violence data comes from press reports collected by the South Asia Terrorism Portal (SATP) between 2007 and 2013. ${ }^{22}$ The SATP draws from newspaper reports in the local and national English speaking press to construct daily incident summaries. These summaries provide the district in which the incident took place, as well as the number of deaths on each side of the conflict (civilians, Maoists and security forces). In these reports, only Maoists inflict civilian casualties. The SATP data assume that all police violence is directed against Maoists, so it probably misclassifies some civilian victims as Maoists. ${ }^{23}$ Based on this information, we construct variables for the number of fatal attacks on Maoists by the police as well as the number of fatal Maoist

\footnotetext{
${ }^{21} \mathrm{~A}$ formalization of this argument can be based on the model of incentives for tax collectors by Khan et al. (2016).

${ }^{22}$ See Vanden Eynde (2018) for further discussion of this data source. The sample period starts in 2007, because the baseline information on mining activity was published in 2006, and because the most recent royalty change (for coal only) was introduced in the first half of 2007. In addition, the SATP data is more complete from 2007 onward (Gawande et al., 2017).

${ }^{23}$ As we are interested in measuring state-initiated violence in the Maoist zones, the distinction between civilian and Maoist victims of police violence is not crucial for our analysis.
} 
attacks on the police. The conflict outcome data are collected at the district level for each half-year between 2007 and 2013. We restrict analysis to seven states that are confronted with significant Naxalite activity during the period under study: Andhra Pradesh, Bihar, Chhattisgharh, Jharkhand, Maharashtra, Orissa and West Bengal. ${ }^{24}$ Summary statistics are presented in table $1 .^{25}$

For our district-level analysis, we focus on the three most important minerals mined in the Maoist area: iron, bauxite, and coal. These minerals occur in a large number of districts. Data on the location and volume of mineral deposits is obtained from the Geological Survey of India. ${ }^{26}$ As chromite and manganese are concentrated in a small number of districts and we have less detailed information on these deposits, we do not consider them in our main results at the district level. ${ }^{27}$ We combine this data with a series of international mineral prices. ${ }^{28}$ The 2001 census provides a variety of control variables.

We use satellite imagery to measure the size of mining areas and for evidence of truck activity at a sample of 82 iron ore, bauxite, chromite, and manganese mines. ${ }^{29} \mathrm{We}$ compare these measures to administrative lease information from the India Directory

${ }^{24}$ Only the eastern part of Maharashtra is affected by the conflict: we include Bhandara, Gondiya, Garhchiroli, and Chandrapur districts in our analysis.

${ }^{25}$ Per capita incidence of violence is low in these districts. The conflict should be understood as affecting specific rural communities within a large area of India.

${ }^{26}$ For iron ore: "Detailed Information Dossier on Iron Ore in India", 2006, GSI. For Bauxite: "Detailed Information Dossier on Iron Ore in India", 1994, GSI. For coal: "Indian Coal Resources", 2004, GSI. This data is complemented with data on deposit locations (which does not include the size of deposits) for chromite and manganese from the "Mineral Atlas of India" (Geological Survey of India, 2001).

${ }^{27}$ We include these minerals as a robustness check in table A11.

${ }^{28}$ We use the price of aluminum at the London Metal Exchange for bauxite, the price of Brazilian Iron Ore, and the price of South African Coal.

${ }^{29}$ Mines in our sample are drawn from those for which lease information allowed for geolocalization based on detectable mining activity and the name of the mining site. Mines that do not have at least one measurement before and after 2009 are not included in our sample. Table A18 confirms that mines included in our sample are slightly larger on average, but the size of the effect is small. Included mines also do not differ in terms of the lease expiration year. 
of Mining Leases (collected in 2015) to identify two types of potential illegal mining activity: (1) truck activity in mines for which the lease has expired, and (2) mining areas that exceed the mine's legal maximum size. We cannot construct these measures for coal as the lease directory does not include coal mines (which are all state-owned). However, we do include chromite and manganese mines at the mine-level..$^{30}$

\section{Empirical strategy and results}

\subsection{Violent conflict}

We use a continuous difference-in-difference approach to understand the impact of the introduction of a $10 \%$ ad valorem tax on iron ore in 2009. Comparing districts with different levels of iron ore deposits before and after the introduction of the new tax rate allows us to isolate the impact of the change. Figure 1 provides a graphical depiction of the identification strategy. It plots the interactions of the volume of iron ore deposits and dummies for each half-year, from a regression of the inverse hyperbolic sine (asinh) of the number of attacks on state-time dummies. Districts with important iron ore deposits experienced a strong and sustained increase in conflict relative to other districts after 2009. This intensification weakens in later years. There are no similar effects for bauxite and coal deposits.

In the main econometric specification, we rely on a fixed-effect OLS regression:

$$
y_{i, s, t}=\alpha_{i}+\text { Bron }_{i, s} * \text { Post }_{t}+\gamma \text { Iron }_{i, s} * \log (\text { Iron Price })_{t}+\mu_{s, t}+\epsilon_{i, s, t}
$$

The dependent variable is either a dummy indicator, or the asinh of the number

\footnotetext{
${ }^{30}$ At the mine level, the geographical concentration of deposits does not hamper the analysis. To alleviate concerns about the asymmetry in the district-level violence results and the mining results, table A11 presents results including manganese and chromite measures. Table A16 confirms that the main violence results hold in a sample of districts containing iron, bauxite, manganese, or chromite deposits, as well as in a sample including only districts for which we have mines in our mining sample.
} 
of fatal attacks inflicted by the Police or Maoists. ${ }^{31}$ Observations are at the level of a district $i$, in state $s$, and in half-year $t$. The indicator variable Post $_{t}$ switches on when the negotiations for the new royalty regime are reported to have started (in the first half of 2009). In the baseline specification, Iron is the logarithm of the mining deposits (in million tonnes per $1000 \mathrm{~km}^{2}$ plus one). ${ }^{32}$ The coefficient $\beta$ represents the difference in the extent or intensity of violence for a one unit increase in our iron ore measure, before and after 2009. We control for the potential impact of international mining prices (which were volatile in our sample period) by including an interaction of Iron with the logarithm of the international iron ore price. ${ }^{33}$ The ad valorem regime could have reinforced price changes - and we discuss this possibility below.

The state-specific time fixed effects $\mu_{s, t}$ account for state-level policy variables which may affect the number of attacks. ${ }^{34}$ As both economic policies and counterinsurgency strategies are set at the state level and vary between states, $\mu_{s, t}$ controls flexibly for a wide range of unobserved determinants of violence. The state-time-fixed effects also absorb the impact of the royalty regime on the state budget, as royalty collections are not tied to expenditures in the districts where they originate. This approach helps us to identify the impact of changed incentives for engaging in conflict (as opposed to a budgetary windfall) at the district level.

${ }^{31}$ The asinh transformation is mathematically close to a $\log (\mathrm{x}+1)$ transformation. We confirm the robustness of our results to using per capita outcomes (table A8) and a Poisson model (table A9).

${ }^{32}$ Panel D of appendix figure A5 shows the conditional distribution of our continuous iron ore deposit measure. Table A12 shows the robustness of the main results to using alternative units of measurement. Figure A7 and table A10 show that the results are also robust to using dummy variables for the presence of deposits.

${ }^{33}$ The evolution of world mineral prices is shown in panel B of figure A2. India's entire iron ore production is only $8.8 \%$ of the total world production (USGS, "Iron Ore Statistics", 2010), which puts the Maoist-affected states in the "price taker" category following the rule of Bazzi and Blattman (2014).

${ }^{34}$ One might be worried about changes in state-level politics around the time of the royalty change. State Assembly elections were held in 2009-10 in five Maoist-affected states, but the Chief Minister's party remained the same post-election in all states except Jharkhand. Table A17 confirms that the results go through when Jharkhand is dropped. 


\subsubsection{Conflict Results}

Table 2 presents the main difference-in-difference estimates for 2007-2011. The coefficient on our treatment variable in column (1) implies that moving from a district without iron ore to a district with the mean deposit value $(1.7$, which is also equal to the standard deviation for strictly positive values) increases the probability of fatal police attacks on Maoists by approximately $12 \%$ points $\left(0.068^{*} 1.7=0.12\right)$. The probability of Maoist attacks on the police increases by around $6 \%$ points $\left(0.035^{*} 1.7=0.06\right)$. As for the intensity of violence, the estimates in columns (2) and (5) suggest that the number of attacks goes up by around $12 \%\left(0.067^{*} 1.7=0.12\right)$. Interestingly, police violence is only weakly higher when prices increase and Maoist violence is uncorrelated with prices. This suggests that the post-royalty hike increase is due to a specific policy decision and not a mechanical reflection of the value of deposits.

While we do not have a clear prior about the exact duration of the impact, we expect the intensification to be limited over time as the conflict has moved to a new equilibrium, in which the state may for example have reached its desired level of control. The event study graphs in figure 1 show that the effect is concentrated in the first three years after the treatment, which is why we use 2007-2011 as our main estimation window. ${ }^{35}$

Taken together, these results are more consistent with violence being driven by changing incentives for the state governments than with mining firms funding the conflict (even if the evidence is not conclusive). First, the violence effect fades out over time, which is consistent with the state establishing its desired level of control. Second, we find relatively weak impacts of prices on conflict (see table 2), even though economically prices are as relevant for the mining firms as the royalty rate (which is not true for the government-the price changes, while up to $100 \%$, are small compared to the approximately $500 \%$ immediate revenue increase to the states through the royalty regime change).

We also cannot fully rule out a wealth effect in which states invest more in countering Naxalite activity when they receive a positive revenue shock. However, revenues are

\footnotetext{
${ }^{35}$ Table A14 shows the sensitivity of the results to the window.
} 
centralized at the state level, and the state-time-fixed effects absorb the impact of the royalty regime at that level. Therefore, our results are more consistent with a change in the incentives to control mining districts.

\subsubsection{Conflict Robustness}

Our results are based on a difference-in-difference approach, so the identification assumption is that iron districts would have followed the same trend in the absence of the royalty change. The pre-treatment trends in figure 1 add credibility to this assumption. ${ }^{36}$ Another way to assess the plausibility of this assumption is to check whether there were increases in conflict related to other mineral deposits. Bauxite saw a small royalty increase in 2009, and the royalty for coal was unchanged. If the main motivation for increasing effort in the vicinity of iron mines was to ensure revenue went to the state, then we would expect a small increase for bauxite deposits and no change for coal deposits. Table 2 confirms that this is the case. ${ }^{37}$

The online appendix tables present a range of important robustness checks. Table A3 provides balance checks, showing weak correlations between our iron ore deposit measure and initial levels of violence. Table A4 confirms that the main coefficients remain statistically significant when we interact a post-treatment dummy with baseline characteristics, including the rural literacy rate, the rural scheduled tribe/caste population, the percentage forest cover, the percentage of villages connected by roads, and the population density. Table A5 further confirms that the results are robust to controlling for different measures of 'Integrated Action Plan' investment. The IAP is a development program targeted at Maoist-affected districts and introduced in 2009, but it did not benefit iron-rich districts in particular. Table A6 tests if the royalty change strengthened the

\footnotetext{
${ }^{36}$ The notes in figure A6 present F-tests of the pre-treatment coefficients.

${ }^{37}$ The effect on bauxite is positive and significantly different from the effect on iron ore for Police attacks on Maoists: for a one standard deviation change in the conditional deposit value, the p-value on the difference in effects is 0.07 for Police attacks on Maoists, while it is 0.04 for Maoist attacks on Police). Figures A7 and A8 are presented to facilitate the comparison of effects across minerals. The modest, positive bauxite effect is imprecisely estimated (due to the small number of bauxite districts), and not sustained over time (it is concentrated in the announcement period), nor across violence types.
} 
effect of prices on conflict. Due to the ad valorem nature of the tax, one might have expected prices to have a stronger impact on violence after 2009. Indeed, the price increase in iron ore in 2009 (as shown in appendix figure A2) contributed to the value royalty collections. In this sense, the treatment is bundled. In table A6, we interact the difference-in-difference treatment with prices. The positive coefficient on this triple interaction consistent with the reinforcing effect of prices, but it does not gain significance. Finally, table A17 confirms that the main results go through in a sample of iron ore districts and their geographical neighbours.

A final concern is that our results might be over-estimated because of re-allocation into iron-mining districts (so the coefficient on iron deposits combines an intensification there with a reduction elsewhere). Such reallocation does not affect the sign of our effect, but it matters for its interpretation. Since counter-Naxalite operations are a statelevel responsibility, we should not see allocation across states. Re-allocation is possible within states in two ways: (1) reallocation of effort across districts; and (2) reallocation of policing effort across tasks within states (i.e. shifting some resources from investigations to counter-Naxal operations). Substitution across districts would imply a symmetric effect, increases in iron districts (and maybe bauxite), reductions elsewhere. We find mixed evidence of this in that there are modest (but insignificant) increases in bauxite areas and reductions in coal-producing districts. In appendix table A13, we show that the results are robust to removing districts bordering iron ore districts or to removing districts with bauxite and coal deposits. This evidence rules out two of the most natural reallocation patterns as drivers of our findings.

\subsection{Illegal mining}

We analyze the effect of the royalty change on illegal mining activity with satellite-based measures for a sample of 82 mining sites (36 iron mines, 15 bauxite mines, 29 manganese mines and 2 chromite mines) for which our data provider had high-resolution imagery in multiple years (the time period we study was before high-resolution satellite imagery coverage became available). The empirical strategy follows a similar difference- 
in-difference approach, comparing iron ore to non-iron ore mines, including mine fixed effects and state-year fixed effects. However, this analysis has to deal with missing measurements in multiple years for any given mine, i.e. the panel is unbalanced. To make sure that composition effects are not driving our findings, we complete the panel by substituting missing observations with the most recent earlier measurements for those mines. ${ }^{38}$ Tables A19 and A20 confirm that the missingness of observations is not explained by our treatment. ${ }^{39}$

The introduction of the $10 \%$ royalty was followed by an increase in the share of iron ore mines that are larger than their official size (compared to non-iron mines), as shown in table 3 (in columns 1 and 2). The probability of iron mines exceeding their legal area increases by around $15 \%$ points. While iron ore mines see a reduction in measured truck activity, there is a net increase of around $20 \%$ points for mines of which the lease has expired (column 3). Figure 2 confirms these findings in an event study graph. Both proxies of illegal mining activity point towards an increase in illegal mining. These tests are somewhat underpowered due to the limited number of observations. In addition, our measures of illegal mining are proxies and do not capture all kinds of illegal mining. Still, the evidence suggests that the royalty hike increases the willingness to pay bribes. More broadly, the response of illegal mining indicates that the mining sector is part of the mechanism that explains our findings for violent conflict. State governments could boost their counterinsurgency efforts to extract higher rents from mining activity, or mining firms could attempt to boost Maoist activity to shield illegal activities. Both mechanisms underline that fiscal policies shape the incentives of actors to engage in conflict, even if we cannot distinguish between these explanations.

\footnotetext{
${ }^{38}$ For certain mines with no information in 2007, we use measurements from 2005-2006. The imputation approach is equivalent to weighting the unimputed panel so that every mine contributes equally.

${ }^{39}$ Table A21 shows robustness to alternative ways of balancing the sample.
} 


\section{Conclusion}

This paper is one of the first to explore the public finance of law and order provision in an ongoing civil conflict. In the federal political structure of India, we study the introduction of a royalty regime for iron ore that strongly increased the fiscal value of iron-rich districts for state governments. As the states are responsible for the provision of law and order in their territory, they play an essential role in the management of the Naxalite conflict.

Our difference-in-difference empirical analysis shows that the introduction of this tax led to a temporary intensification of Maoist-related violence. These results are consistent with (1) the allocation of security operations according to the value of controlling territory, or (2) mining operations funding conflict to be able to evade paying royalties.

Our results are part of an emerging research agenda which recognizes the institutionalized nature of conflicts. Many developing countries are decentralizing political power, while managing important natural resource deposits. Understanding how the fiscal regimes that govern resource extraction shape violent conflict has clear relevance beyond India. 


\section{References}

Asher, Sam and Paul Novosad. "Rent-Seeking and Criminal Politicians : Evidence from Mining Booms," Working paper available at SSRN 2812315 (2020).

Bazzi, Samuel and Christopher Blattman. "Economic shocks and conflict: Evidence from commodity prices," American Economic Journal: Macroeconomics 6 (2014): 1-38.

Berman, Eli and Aila M. Matanock. "The empiricists' insurgency," Annual Review of Political Science 18 (2015): 443-464.

Berman, Nicolas, Mathieu Couttenier, Dominic Rohner, and Mathias Thoenig. “This mine is mine! How minerals fuel conflicts in Africa," American Economic Review 107 (2017): 1564-1610.

Brückner, Markus and Antonio Ciccone. "International commodity prices, growth and the outbreak of civil war in Sub-Saharan Africa," Economic Journal 120 (2010): 519-534.

Ch, Rafael, Jacob Shapiro, Abbey Steele, and Juan F. Vargas. "Endogenous Taxation in Ongoing Internal Conflict: The Case of Colombia," American Political Science Review 112 (2018): 905-917.

Christensen, Darin, Mai Nguyen, and Renard Sexton. "Strategic Violence during Democratization: Evidence from Myanmar," World Politics 71 (2019): 332-366.

Dal Bó, Ernesto and Pedro Dal Bó. "Workers, warriors, and criminals: Social conflict in general equilibrium," Journal of the European Economic Association 9 (2011): 646-677.

Dube, Oeindrila and Juan F. Vargas. "Commodity price shocks and civil conflict: Evidence from Colombia," Review of Economic Studies 80 (2013): 1384-1421.

Fetzer, Thiemo. "Can Workfare Programs Moderate Conflict? Evidence from India," Journal of the European Economic Association (2020).

Fetzer, Thiemo and Stephan Kyburz. "Cohesive Institutions and Political Violence," CAGE Working Paper (2019). 
Gawande, Kishore, Devesh Kapur, and Shanker Satyanath. "Renewable Natural Resource Shocks and Conflict Intensity: Findings from India's Ongoing Maoist Insurgency," Journal of Conflict Resolution 61 (2017): 140-172.

Ghatak, Maitreesh and Oliver Vanden Eynde. "Economic Determinants of the Maoist Conflict in India," Economic \& Political Weekly 52 (2017): 69-76.

Khan, Adnan Q., Asim I. Khwaja, and Benjamin A. Olken. "Tax farming redux: Experimental evidence on performance pay for tax collectors," Quarterly Journal of Economics 131 (2016): 219-271.

Khanna, Gaurav and Laura Zimmermann. "Guns and butter? Fighting violence with the promise of development," Journal of Development Economics 124 (2017): 120-141.

Kujur, Rajat Kumar. "Naxal conflict in 2008: An assessment," IPCS Report (Institute of Peace and Conflict) (2009).

Lei, Yu Hsiang and Guy Michaels. "Do giant oilfield discoveries fuel internal armed conflicts?" Journal of Development Economics 110 (2014): 139-157.

Romero, Mauricio and Santiago Saavedra. "Local incentives and national tax evasion: Unintended effects of a mining reform in Colombia," Universidad del Rosario Working Paper (2019).

Sánchez de la Sierra, Raúl. "On the origins of the state: Stationary bandits and taxation in Eastern Congo," Journal of Political Economy 128 (2020): 32-74.

Srivastava, Devyani. "Terrorism \& Armed Violence in India," IPCS Special Report (Institute of Peace and Conflict) (2009).

Vanden Eynde, Oliver. "Targets of Violence: Evidence from India's Naxalite Conflict," Economic Journal 128 (2018): 887-916. 


\section{Appendix: Summary Statistics and Main Results}

Table 1: Summary Statistics

Observations Mean Standard Deviation

Panel A: District level measures, time-varying (half-yearly)

Police Attacks on Maoists (0/1)

Maoist Attacks on Police (0/1)

Police Attacks on Maoists (asinh)

Maoist Attacks on Police (asinh)

Police attacks on Maoists (per million)

Maoist attacks on Police (per million)

Panel B: District-level measures, constant

$\log ($ Iron Deposit)

Log(Bauxite Deposit)

$\log$ (Coal Deposit)

Iron Deposits (0-1)

Bauxite Deposits (0-1)

Coal Deposits (0-1)

Log(Iron Deposit), positive

Log(Bauxite Deposit), positive

Log(Coal Deposit), positive
2016

2016

2016

2016

2016

2016

144

144

144

144

144

144

28

18

26

Panel C: Time-varying measures (half-yearly)

Log Iron Price (real USD per MT)

14

14

14

0.12

0.11

0.16

0.13

0.20

0.19

1.06

Log Bauxite Price (real USD per MT)

Log Coal Price (real USD per MT)
0.34

0.76

0.44

0.15

0.40

0.19

0.33

0.13

0.39

0.18

1.72

1.74

1.25

1.90

0.70

0.84

0.28

4.86

0.19

7.66

0.25 
Table 1: Summary Statistics - continued

Observations Mean Standard Deviation

(1)

(2)

Panel D: Mine-level measures, time-varying (yearly)

Excess mining area (0-1)

558

0.28

0.45

Excess mining area, at least 50\% (0-1)

558

0.23

0.42

Lease expired before 2009

574

0.45

0.50

Mine with active trucking

558

0.70

0.46

Panel E: Mine-level measures, constant Iron Ore (0-1)

82

0.44

0.50

Bauxite (0-1)

82

0.18

0.39

Chromite (0-1)

82

0.02

0.16

Manganese (0-1)

82

0.35

0.48

Notes: Observations at the district-level. The states of Andhra Pradesh, Bihar, Chhattisgarh, Jharkhand, Maharashtra (4 districts), Orissa, and West-Bengal are included in the sample. The text provides a description of our mineral measures from Geological Survey of India. The continuous deposit values are measured as million tonnes (billion tonnes for coal) per 1000 squared $\mathrm{km}$, and subject to a $\log (\mathrm{x}+1)$ transformation. 
Figure 1: Event studies.

(1) Police Attacks on Maoists

Iron Ore Deposits

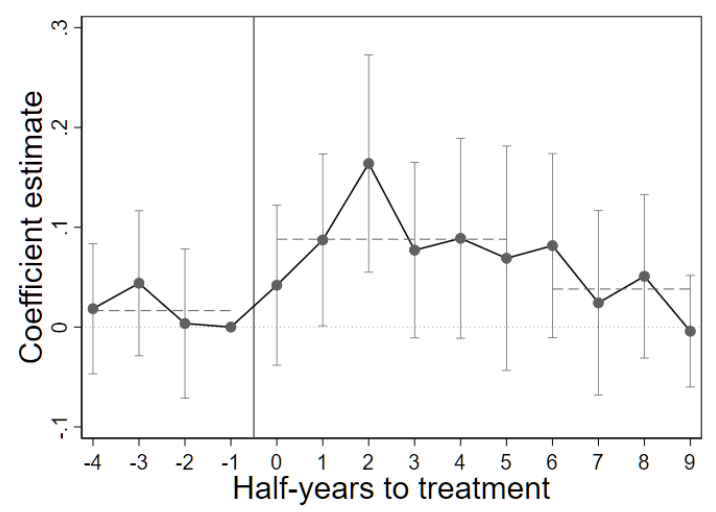

Bauxite Ore Deposits

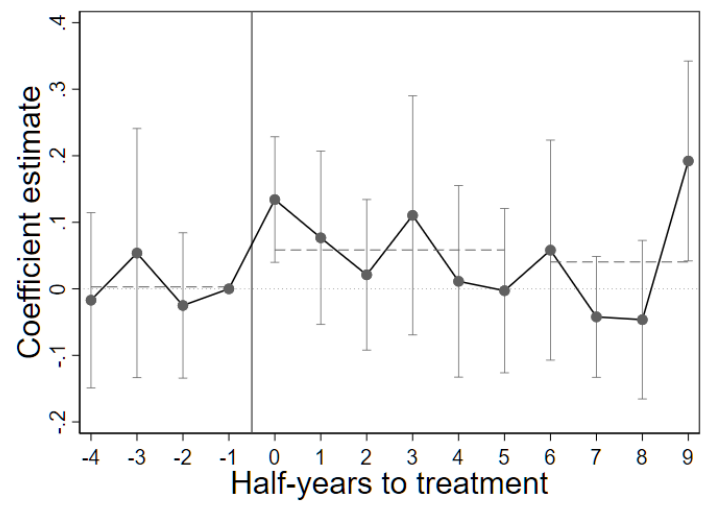

Coal Deposits

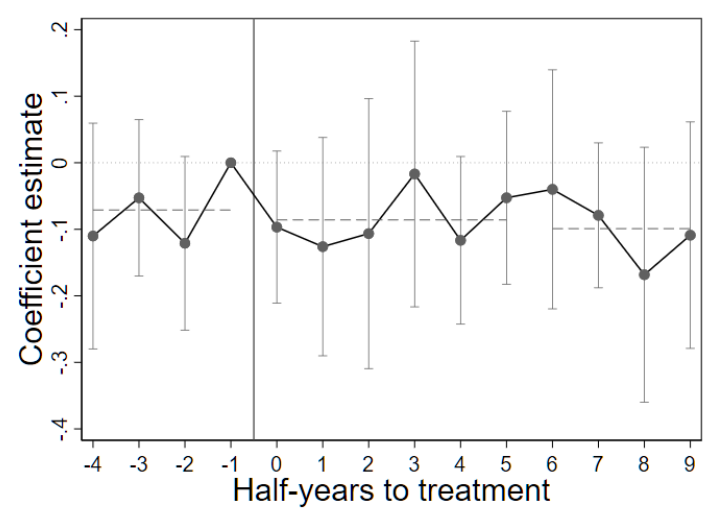

(2) Maoist Attacks on Police
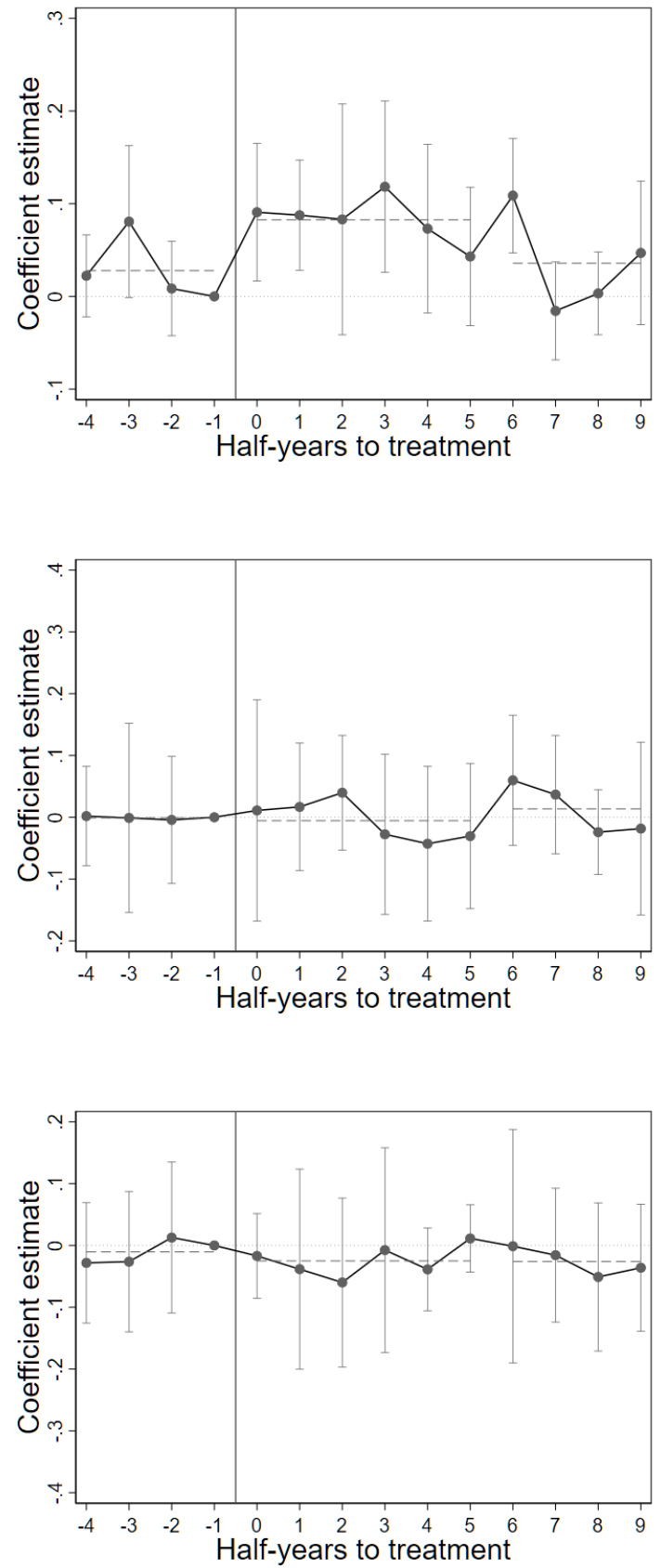

Notes: Half-yearly district-level data between 2007 and 2013. Event studies follow the main specification (equation 1). Outcomes are subject to an asinh transformation. Deposit values are measured as million tonnes (billion tonnes for coal) per 1000 square $\mathrm{km}$, and subject to a $\log (x+1)$ transformation. All regressions include state-time fixed effects. Standard errors are clustered at the district level and 95\% confidence intervals are shown as grey bars. 
Table 2: Main Results

\begin{tabular}{|c|c|c|c|c|c|c|}
\hline & \multicolumn{3}{|c|}{ Police Attacks on Maoists } & \multicolumn{3}{|c|}{ Maoist Attacks on Police } \\
\hline & \multirow{2}{*}{$\frac{\text { Dummy }}{(1)}$} & \multicolumn{2}{|c|}{ Asinh } & \multirow{2}{*}{$\frac{\text { Dummy }}{(4)}$} & \multicolumn{2}{|c|}{ Asinh } \\
\hline & & $(2)$ & (3) & & (5) & (6) \\
\hline \multirow[t]{2}{*}{ Log(Iron Deposit) x Post } & $0.068^{* * *}$ & $0.068^{* * *}$ & $0.074^{* * *}$ & $0.035^{*}$ & $0.056^{* *}$ & $0.054^{* *}$ \\
\hline & $(0.018)$ & $(0.024)$ & $(0.024)$ & $(0.019)$ & $(0.023)$ & $(0.023)$ \\
\hline \multicolumn{7}{|l|}{ Log(Iron Deposit) } \\
\hline \multirow[t]{2}{*}{ x Price (real USD per MT) } & $0.052^{* *}$ & 0.043 & 0.037 & -0.007 & -0.004 & -0.005 \\
\hline & $(0.021)$ & $(0.034)$ & $(0.034)$ & $(0.020)$ & $(0.026)$ & $(0.026)$ \\
\hline \multirow[t]{2}{*}{ Log(Bauxite Deposit) $x$ Post } & & & 0.016 & & & -0.019 \\
\hline & & & $(0.034)$ & & & $(0.036)$ \\
\hline \multirow[t]{2}{*}{ Log(Coal Deposit) x Post } & & & -0.018 & & & -0.017 \\
\hline & & & $(0.042)$ & & & $(0.027)$ \\
\hline \multicolumn{7}{|l|}{ Log(Bauxite Deposit) } \\
\hline \multirow[t]{2}{*}{ x Price (real USD per MT) } & & & -0.180 & & & -0.067 \\
\hline & & & $(0.116)$ & & & $(0.115)$ \\
\hline \multicolumn{7}{|l|}{ Log(Coal Deposit) } \\
\hline \multirow[t]{2}{*}{ x Price (real USD per MT) } & & & 0.070 & & & 0.053 \\
\hline & & & $(0.057)$ & & & $(0.060)$ \\
\hline Mean DV & 0.140 & 0.175 & 0.175 & 0.116 & 0.136 & 0.136 \\
\hline Observations & 1440 & 1440 & 1440 & 1440 & 1440 & 1440 \\
\hline Clusters & 144 & 144 & 144 & 144 & 144 & 144 \\
\hline
\end{tabular}

Notes: Regressions at the district-half-year level (2007-2011). All regressions include district fixed effects, and state $\times$ time fixed effects. Standard errors are clustered at the district level and presented in parentheses; stars indicate ${ }^{* *} p<0.01,{ }^{* *} p<0.05,{ }^{*} p<0.1$. 
Table 3: Illegal Mining

Excess Mining (0-1) Excess Mining $50 \%$ threshold (0-1) Truck Activity (0-1)

(1)

Iron Mine x (2009-2011)

Iron Mine x (2012-2013)

Iron Mine x (2009-2011) x Expired

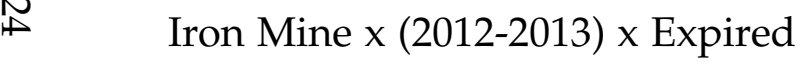

$0.132^{*}$

$0.156^{* *}$

$(0.068)$

(2)

$0.127^{* *}$

$0.132^{* *}$

(3)

$-0.141^{*}$

$-0.088$

$-0.044$

(0.175)

Mean DV

Observations

0.276

558

0.228

0.701

Clusters
558

82
558

82

Notes: Annual mine-level data between 2007 and 2013. Truck activity and area measurements are based on satellite imagery analysed for the purpose of this study. The illegal mining proxies are based on comparing satellite information with the legal area and expiration date from the India Directory of Mining Leases. The excess mining indicator is equal to 1 when the measured area exceeds the legal area (by more than 50\% in column 2). Control minerals include: bauxite, manganese, and chromite. Regressions include mine, state $\times$ time, and (in column 3) expired status $\times$ time fixed effects. Standard errors are clustered at the mine level and presented in parentheses; stars indicate ${ }^{* * *} p<0.01$, ** $p<0.05, * p<0.1$. 
Figure 2: Illegal Mining

Panel A: Excess Mining (0-1)

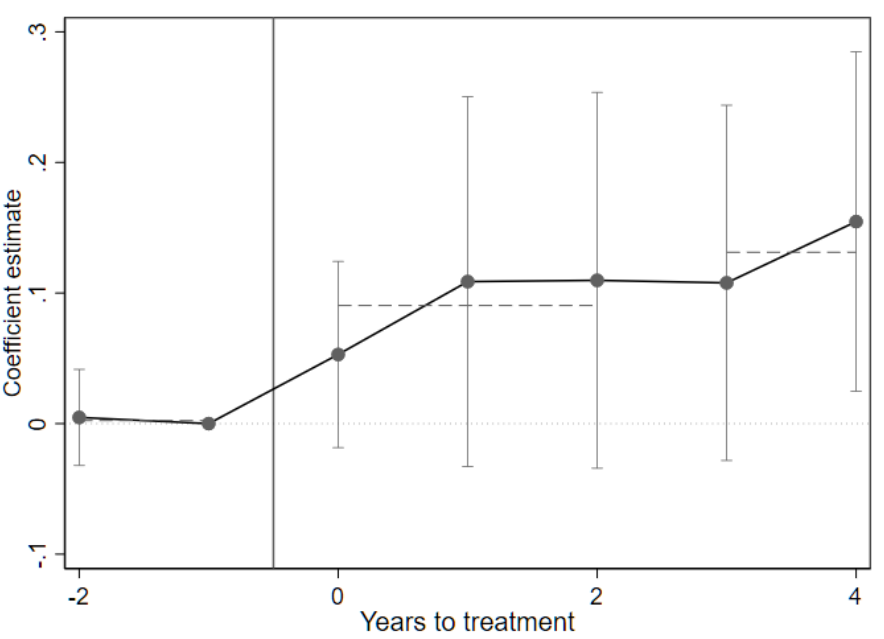

Panel B: Truck Activity in Expired Mines (0-1)

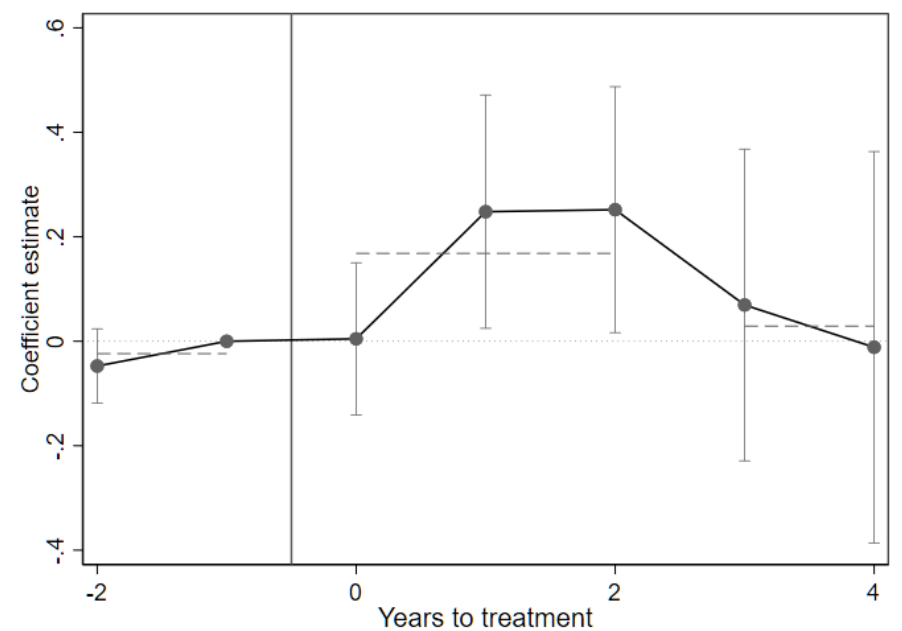

Notes: Annual mine-level data between 2007 and 2013. The event studies show coefficients on the interaction of an iron ore indicator with a year dummy in Panel A; and the interaction of iron ore, expiration status, and year dummies in panel B. Truck activity and area measurements are based on satellite imagery analysed for the purpose of this study. The illegal mining proxies are based on comparing satellite information with the legal area and expiration date from the India Directory of Mining Leases. The excess mining indicator is equal to 1 when the measured area exceeds the legal area (by more than 50\% in column 2). Control minerals include: bauxite, manganese, and chromite. Regressions include mine, state $\times$ time, and (in column 3) expired status $\times$ time fixed effects. $95 \%$ confidence intervals are shown around each coefficient. 


\section{Online Appendix to "Fiscal Incentives for Conflict: Evidence from India's Red Corridor"}

Figure A1: District sample on a map of Indian States

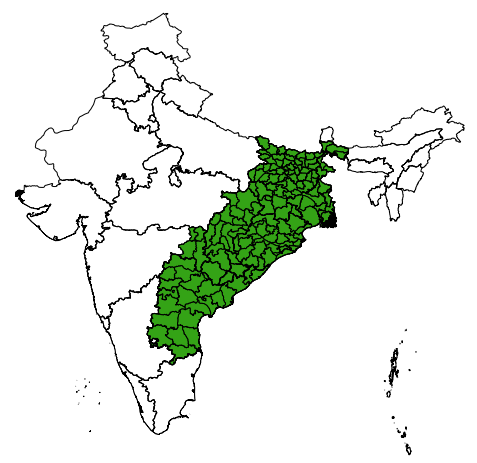

Notes: Districts included in our main sample (the map does not show disputed territories).

Figure A2: Iron ore output and mineral prices

Panel A: Iron output (India-wide) Panel B: World Mineral Prices
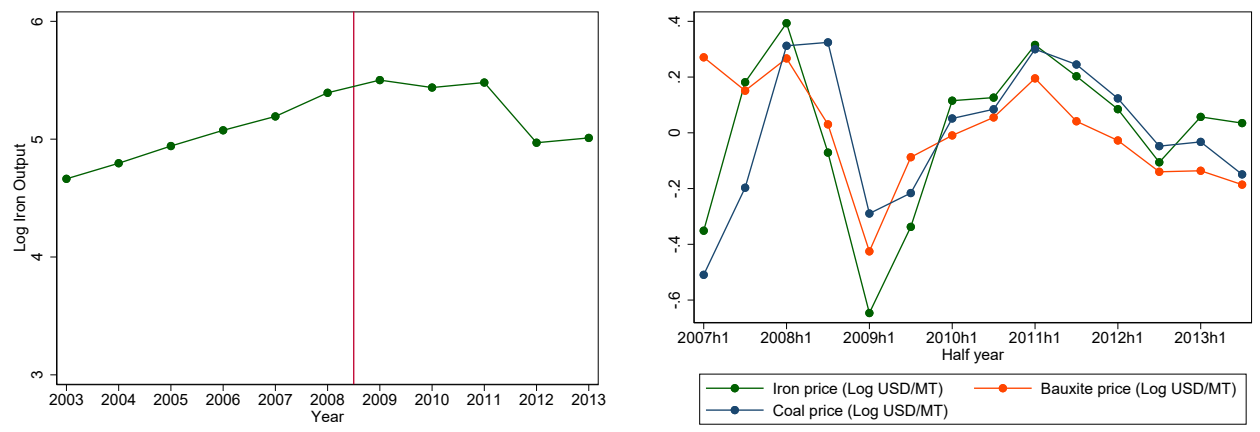

Notes: Panel A: Aggregate output of log(iron ore) production in India between 2003 and 2013 in millions of metric tonnes. Panel B: logarithm of world mineral prices (from Global Financial Data), demeaned. The aluminum price is used for bauxite. 
Figure A3: Mineral resources

Panel A: Distribution of mineral deposits

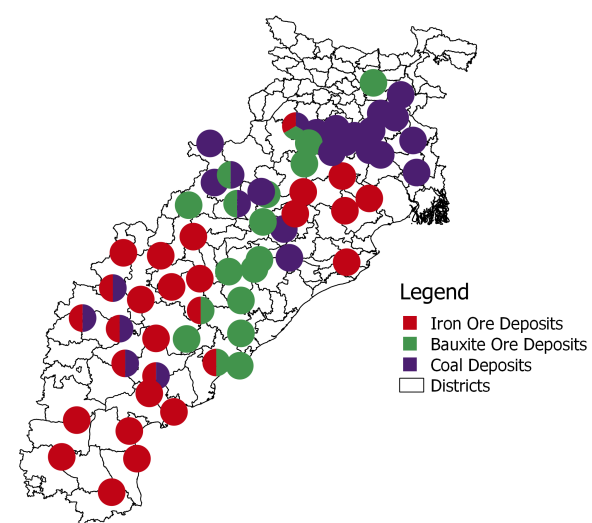

Panel B: Location of mines with satellite measures

Notes: Panel A: District-level mineral deposits (dummy indicators) for our main sample. Panel ${ }^{\mathrm{B}}$ shows the coordinates of mines for which satellite

measurements were available and that are included in our sample.

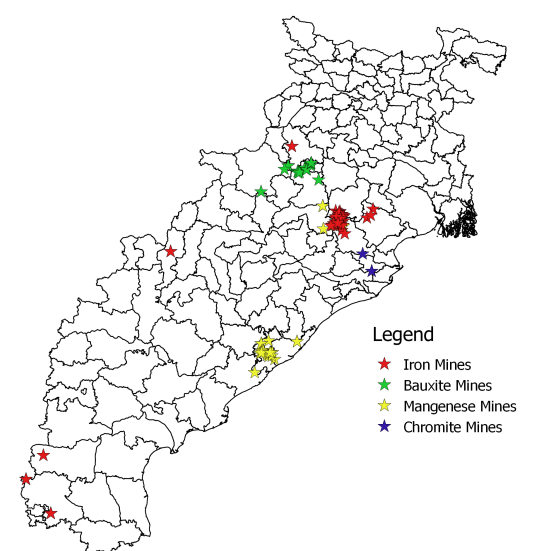

Figure A4: Satellite measurements of mines

Panel A: Measurement of mine areas Panel B: Recognizing truck activity
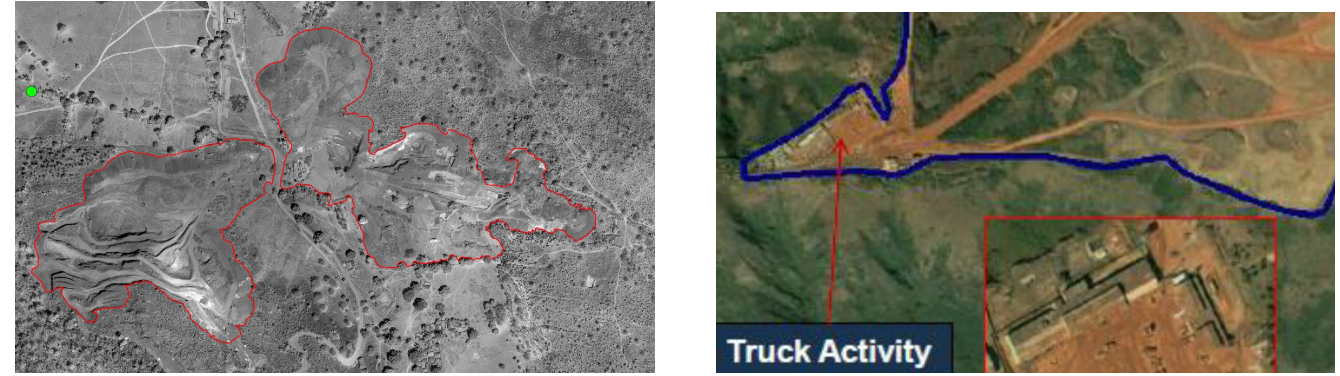

Notes: Panels A and B give examples of the raw image data that was used by our data provider to calculate the area of mines and truck activity. 
Figure A5: Violence and Iron Ore

Panel A: Police Attacks on Maoists

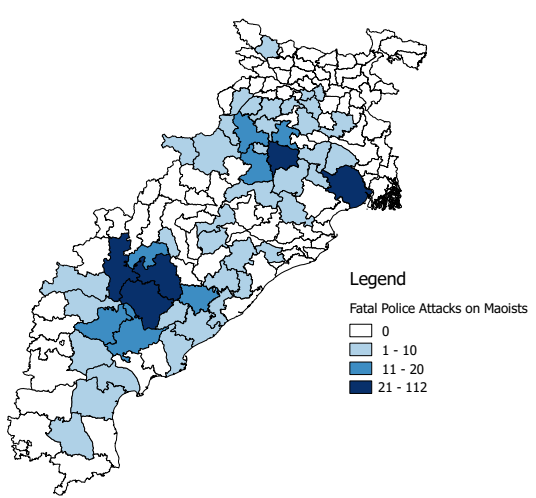

Panel C: Iron Ore Deposits

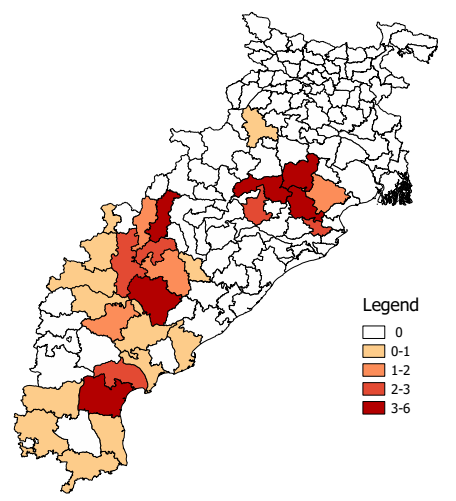

Panel B: Maoist Attacks on Police

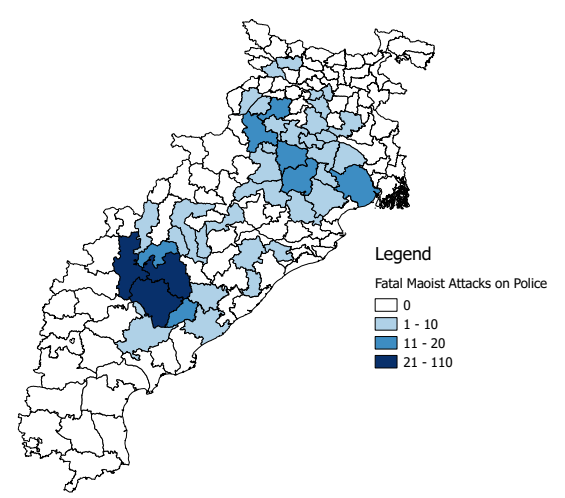

Panel D: Distribution of iron ore deposit measure

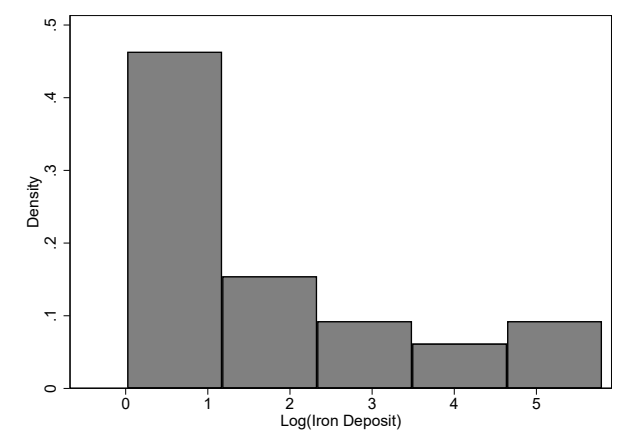

Notes: Panels A and B: District-level totals between 2007 and 2013. Panels C and D: deposit values measured at the district level as million tonnes (billion tonnes for coal) per 1000 squared $\mathrm{km}$, and subject to a $\log (\mathrm{x}+1)$ transformation. 
Figure A6: Event studies for Iron Ore Deposits.

\section{Panel A: Police Attacks on Maoists (dummy) Panel B: Maoist Attacks on Police (dummy)}

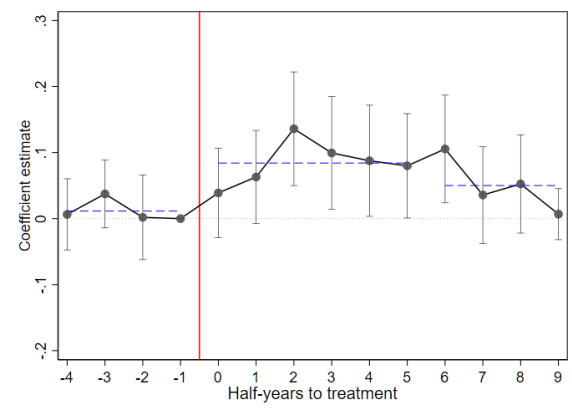

Panel C Police Attacks on Maoists (asinh)

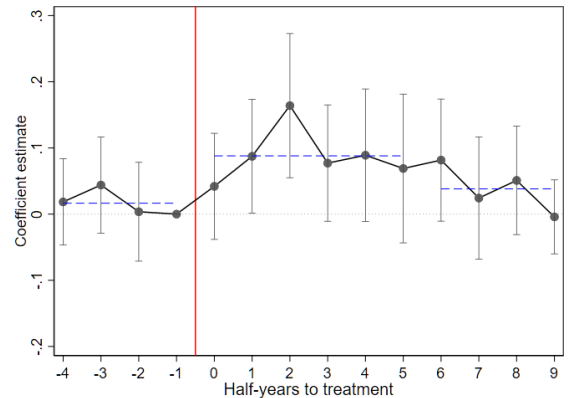

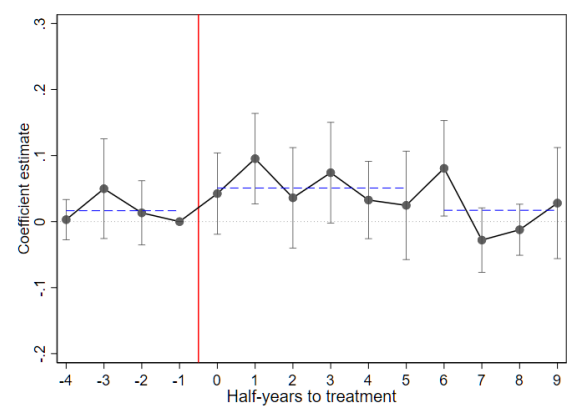

Panel D: Maoist Attacks on Police (asinh)

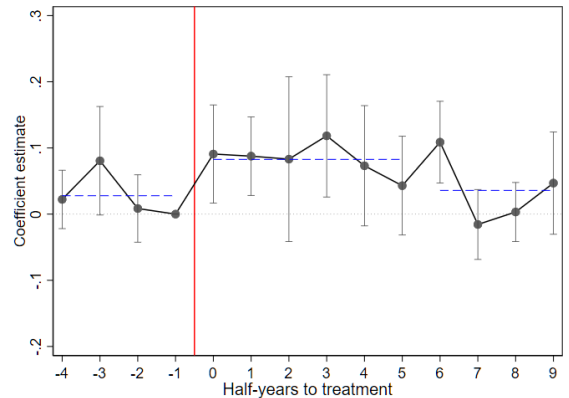

Notes: Half-yearly district-level data between 2007 and 2013. Event studies follow the main specification (equation 1). Deposit values are measured as million tonnes per 1000 squared $\mathrm{km}$, and subject to a $\log (\mathrm{x}+1)$ transformation. All regressions include state-time fixed effects. The p-values for the F-statistics on the pretreatment coefficients are as follows: 0.5016 (Panel A), 0.5483 (Panel B), 0.5504 (Panel C), 0.2386 (Panel D). Standard errors are clustered at the district level and 95\% confidence intervals are shown as grey bars. 
Figure A7: Event studies for Iron Ore Deposits - dummy mining measure Panel A: Police Attacks on Maoists (dummy) Panel B: Maoist Attacks on Police (dummy)

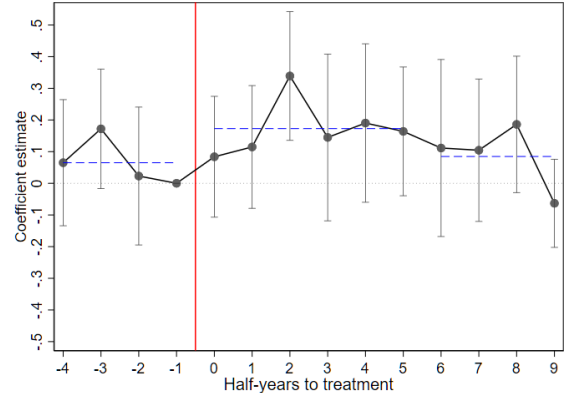

Panel C Police Attacks on Maoists (asinh)

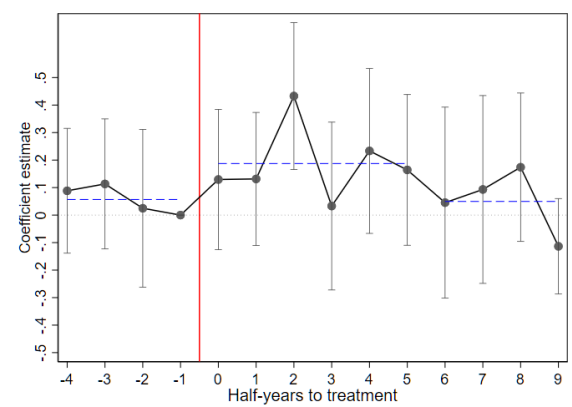

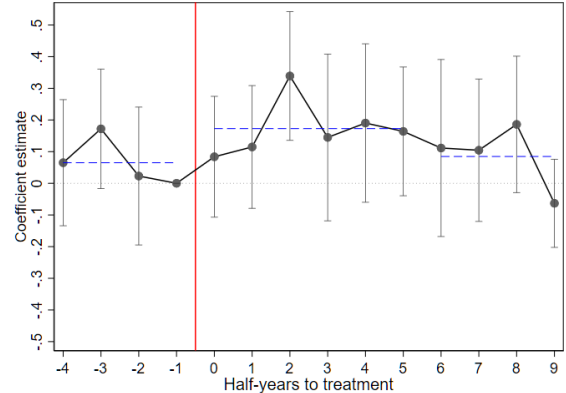

Panel D: Maoist Attacks on Police (asinh)

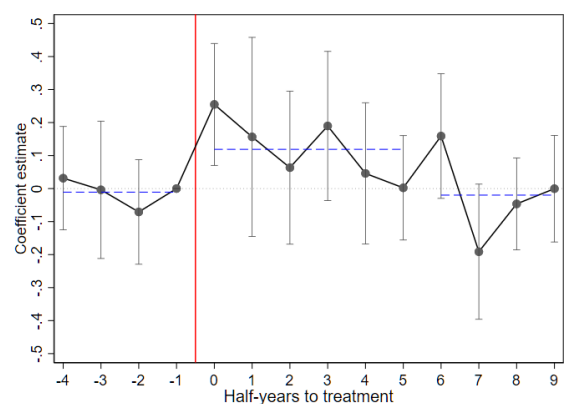

Notes: Half-yearly district-level data between 2007 and 2013. Event studies follow the main specification (equation 1). Deposit values are measured as dummy indicators. All regressions include state-time fixed effects. Standard errors are clustered at the district level and 95\% confidence intervals are shown as grey bars. 
Figure A8: Event studies for three minerals - Comparison

Panel A: Police Attacks on Maoists (dummy)

Iron Ore Deposits

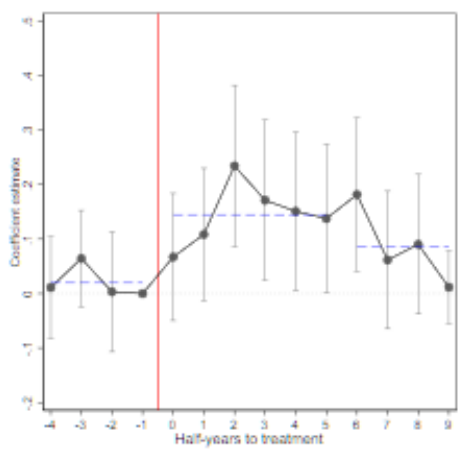

Panel B: Police Attacks on Maoists (asinh)
Bauxite Deposits

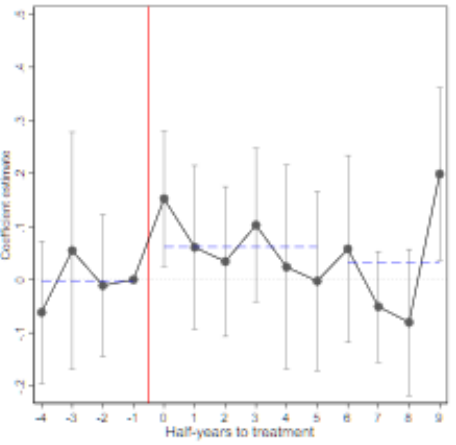

Coal Deposits

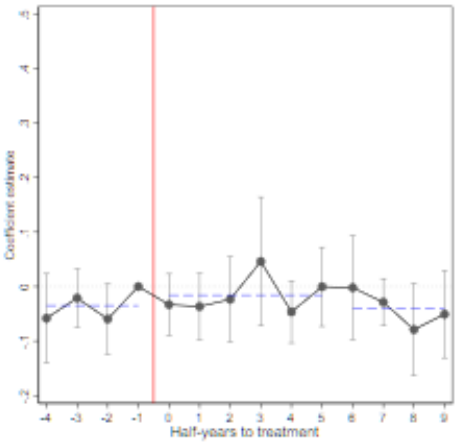

Iron Ore Deposits

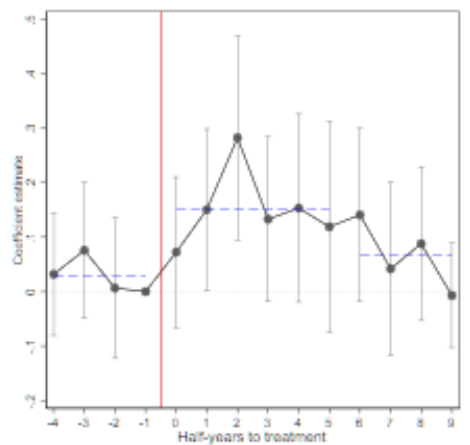

Bauxite Deposits

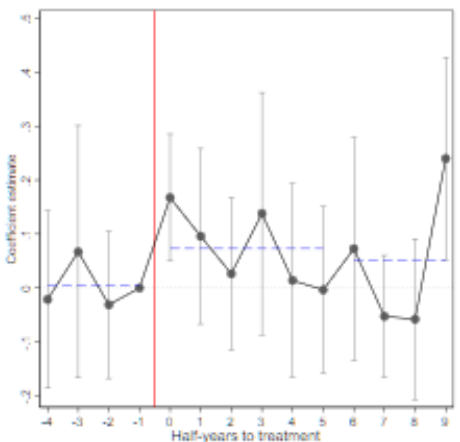

Coal Deposits

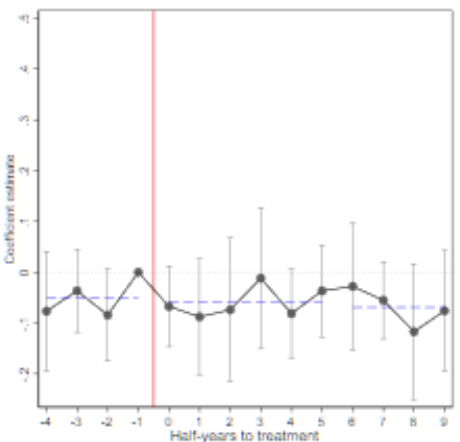

Notes: Notes: Half-yearly district-level data between 2007 and 2013. Event studies follow the main specification (equation 1). Deposit values are measured as million tonnes (billion tonnes for coal) per 1000 squared $\mathrm{km}$, subject to a $\log (\mathrm{x}+1)$ transformation. These measures are divided by their standard deviation (for positive values), to make effect sizes comparable. All regressions include state-time fixed effects. Standard errors are clustered at the district level and $95 \%$ confidence intervals are shown as grey bars. 
Figure A9: Event studies for three minerals - Comparison

\section{Panel A: Maoist Attacks on Police (dummy)}
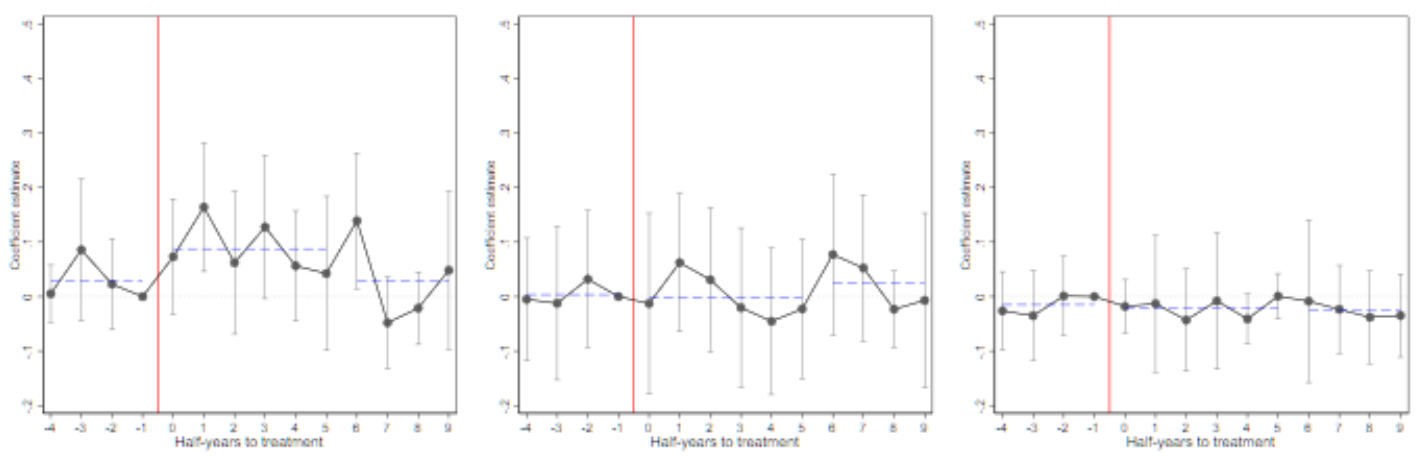

Panel B: Maoist Attacks on Police (asinh)
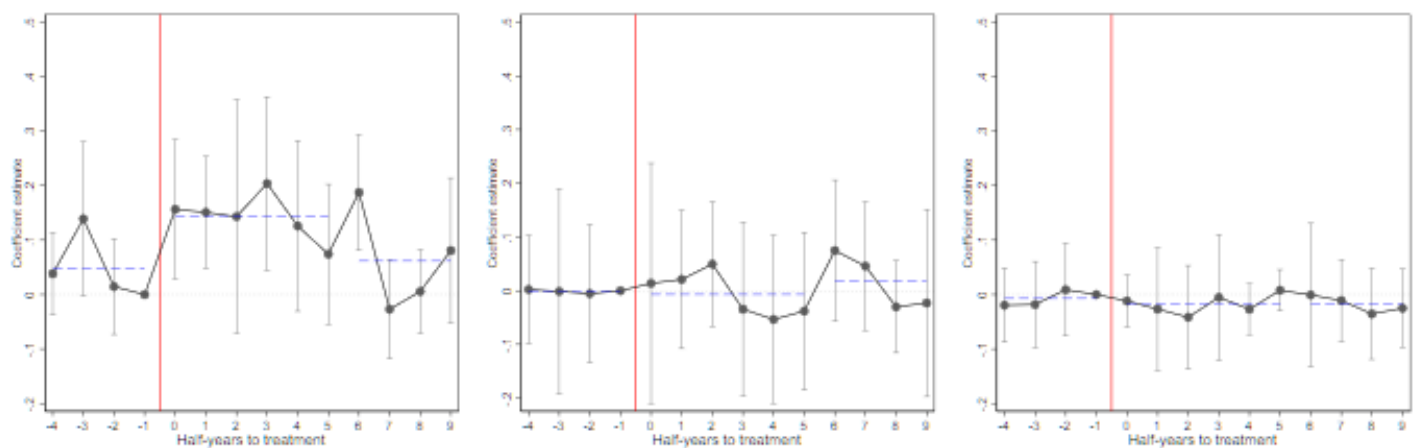

Notes: Half-yearly district-level data between 2007 and 2013. Event studies follow the main specification (equation 1). Deposit values are measured as million tonnes (billion tonnes for coal) per 1000 squared $\mathrm{km}$, and subject to a $\log (\mathrm{x}+1)$ transformation. These measures are divided by their standard deviation (for positive values), to make effect sizes comparable. All regressions include state-time fixed effects. $95 \%$ confidence intervals are shown as grey bars. 
Table A1: State-wise Royalty Collection of Iron Ore in India (Million \$)

\begin{tabular}{lccccc}
\hline States & & \multicolumn{5}{c}{ \% of GDP } & $\begin{array}{c}\text { \% of Budget } \\
\text { 2008-09 }\end{array}$ & $2009-10$ & $2010-11$ & $2010-11$ & 2.10 \\
\hline Andhra Pradesh & 3.3 & 5.9 & 2.1 & & \\
Chhattisgarh & 12.1 & 70.9 & 203.8 & 0.9 & 4.5 \\
Jharkhand & 6.9 & 30.5 & 70.9 & 0.5 & 1.8 \\
Maharashtra & 0.1 & 0.3 & 4.0 & & \\
Odisha & 29.5 & 132.1 & 365.9 & 0.9 & 5.4 \\
\hline
\end{tabular}

Source: Royalty figures from Lok Sabha Starred Question No. 214 (December 7, 2012). GDP data are from the Ministry of statistics and Program Implementation. State Budget figures (2010-2011) for Jharkhand, Chhattisgarh, and Orissa from the Ministry of Finance.

\section{Table A2: Additional Summary Statistics}

\begin{tabular}{lccc}
\hline & $\begin{array}{c}\text { Number of Observations } \\
(1)\end{array}$ & $\begin{array}{c}\text { Mean } \\
(2)\end{array}$ & $\begin{array}{c}\text { Standard Deviation } \\
(3)\end{array}$ \\
\cline { 2 - 4 } District-level measures & & & \\
Manganese Deposits (0-1) & 144 & 0.04 & 0.20 \\
Chromite Deposits (0-1) & 144 & 0.05 & 0.22 \\
Percentage Literates, Rural, 2001 & 144 & 0.44 & 0.12 \\
ST/SC rate, Rural, 2001 & 144 & 0.34 & 0.18 \\
Percentage of forest area, 2005 & 141 & 20.00 & 18.41 \\
Villages connected by paved road (share), 2001 & 144 & 0.41 & 0.20 \\
Population density (100 per sq km) & 144 & 5.30 & 4.35 \\
Share of the rural population, 2001 & 144 & 0.84 & 0.12 \\
Electrified villages (share), 2001 & 144 & 0.57 & 0.30 \\
Rate of agricultural workers, Rural, 2001 & 144 & 0.22 & 0.07 \\
Drought prone (percentage of area), 2006 & 144 & 1.41 & 6.82 \\
\hline
\end{tabular}

Notes: Observations at the district-level. 'ST/SC' refers to the share of the scheduled tribe/scheduled caste in the rural population. District-level baseline measures are from the 2001 census, with the exception of forest cover ("District-Wise Forest Cover in 2005" from the Ministry of Environment and Forest, Government of India) and drought proneness ("India Vulnerability Atlas", 2006). Mineral measures are from the Geological Survey of India. 
Table A3: Pre-treatment balance — state fixed-effects

\begin{tabular}{|c|c|c|c|c|c|c|c|c|c|c|c|}
\hline & $\begin{array}{c}\text { Police Attacks } \\
\text { on Maoists } \\
(2007-8) \\
(1)\end{array}$ & $\begin{array}{c}\text { Maoist Attacks } \\
\text { on Police } \\
(2007-8) \\
(2)\end{array}$ & $(3)$ & $(4)$ & $(5)$ & $\log (\operatorname{Ir}$ & on Ore D & eposits) & $(9)$ & $(10)$ & $(11)$ \\
\hline Log(Iron Deposit) & $\begin{array}{c}0.761 \\
(0.660)\end{array}$ & $\begin{array}{c}0.311 \\
(0.262)\end{array}$ & & & & & & & & & \\
\hline Log(Bauxite Deposit) & $\begin{array}{l}0.401^{*} \\
(0.221)\end{array}$ & $\begin{array}{c}0.172 \\
(0.134)\end{array}$ & & & & & & & & & \\
\hline Log(Coal Deposit) & $\begin{array}{l}-0.055 \\
(0.145)\end{array}$ & $\begin{array}{l}-0.029 \\
(0.065)\end{array}$ & & & & & & & & & \\
\hline Percentage of forest area, 2005 & & & $\begin{array}{l}0.012^{*} \\
(0.007)\end{array}$ & & & & & & & & \\
\hline Population density (100 per sq km) & & & & $\begin{array}{l}-0.023 \\
(0.016)\end{array}$ & & & & & & & \\
\hline Percentage Literates, Rural, 2001 & & & & & $\begin{array}{l}-0.580 \\
(0.938)\end{array}$ & & & & & & \\
\hline ST/SC rate, Rural, 2001 & & & & & & $\begin{array}{l}2.167^{* *} \\
(0.926)\end{array}$ & & & & & \\
\hline Villages connected by paved road (share), 2001 & & & & & & & $\begin{array}{c}0.573 \\
(0.573)\end{array}$ & & & & \\
\hline Electrified villages (share), 2001 & & & & & & & & $\begin{array}{l}-0.193 \\
(0.597)\end{array}$ & & & \\
\hline Drought prone (percentage of area), 2006 & & & & & & & & & $\begin{array}{c}-0.012^{* *} \\
(0.006)\end{array}$ & & \\
\hline Rate of agricultural workers, Rural, 2001 & & & & & & & & & & $\begin{array}{l}3.294^{* *} \\
(1.509)\end{array}$ & \\
\hline Share of the rural population, 2001 & & & & & & & & & & & $\begin{array}{l}-0.261 \\
(0.740)\end{array}$ \\
\hline Mean DV & 0.421 & 0.192 & 0.346 & 0.339 & 0.339 & 0.339 & 0.339 & 0.339 & 0.339 & 0.339 & 0.339 \\
\hline Standard Deviation & 2.423 & 1.044 & 1.029 & 1.020 & 1.020 & 1.020 & 1.020 & 1.020 & 1.020 & 1.020 & 1.020 \\
\hline Observations & 144 & 144 & 141 & 144 & 144 & 144 & 144 & 144 & 144 & 144 & 144 \\
\hline
\end{tabular}

Notes: Regressions at the district-level. Outcomes in columns 1-2 are measured as total casualties per capita before the iron ore royalty hike (i.e. 2007-2008). Deposit values measured as million tonnes (billion tonnes for coal) per 1000 squared $\mathrm{km}$, and subject to a $\log (\mathrm{x}+1)$ transformation. All regressions include state fixed effects. Robust standard errors are presented in parentheses; ${ }^{* * *} p<0.01,{ }^{* *} p<0.05,{ }^{*} p<0.1$. 
Table A4: Main Results with control variables $\times$ Post

\begin{tabular}{|c|c|c|c|c|c|c|}
\hline & \multicolumn{3}{|c|}{ Police Attacks on Maoists } & \multicolumn{3}{|c|}{ Maoist Attacks on Police } \\
\hline & \multirow{2}{*}{$\frac{\text { Dummy }}{(1)}$} & \multicolumn{2}{|c|}{ Asinh } & \multirow{2}{*}{$\frac{\text { Dummy }}{(4)}$} & \multicolumn{2}{|c|}{ Asinh } \\
\hline & & (2) & (3) & & (5) & (6) \\
\hline Log(Iron Deposit) x Post & $\begin{array}{c}0.061^{* * *} \\
(0.018)\end{array}$ & $\begin{array}{c}0.063^{* * * *} \\
(0.024)\end{array}$ & $\begin{array}{c}0.076^{* * * *} \\
(0.024)\end{array}$ & $\begin{array}{c}0.022 \\
(0.021)\end{array}$ & $\begin{array}{c}0.046^{*} \\
(0.025)\end{array}$ & $\begin{array}{l}0.044^{*} \\
(0.026)\end{array}$ \\
\hline Log(Bauxite Deposit) $x$ Post & & & $\begin{array}{c}0.034 \\
(0.042)\end{array}$ & & & $\begin{array}{l}-0.025 \\
(0.031)\end{array}$ \\
\hline Log(Coal Deposit) $x$ Post & & & $\begin{array}{c}-0.033 \\
(0.035)\end{array}$ & & & $\begin{array}{c}0.015 \\
(0.033)\end{array}$ \\
\hline Mean DV & 0.143 & 0.178 & 0.178 & 0.118 & 0.139 & 0.139 \\
\hline Standard Deviation & 0.350 & 0.487 & 0.487 & 0.323 & 0.422 & 0.422 \\
\hline Observations & 1410 & 1410 & 1410 & 1410 & 1410 & 1410 \\
\hline Clusters & 141 & 141 & 141 & 141 & 141 & 141 \\
\hline $\begin{array}{l}\text { Notes: Regressions at the dist } \\
\text { is interacted with post-treatme } \\
\text { of scheduled tribe/scheduled } \\
\text { cover, the share of villages co } \\
\text { of the rural population, the sh } \\
\text { and the percentage of drough } \\
\text { state } \times \text { time fixed effects, and } \\
\text { at the district level; } * * * p<0.0\end{array}$ & $\begin{array}{l}\text { rict-half-ye } \\
\text { ent dummie } \\
\text { caste (ST/S } \\
\text { nnected by } \\
\text { are of elect } \\
\text { t-prone are } \\
\text { mineral } \times\end{array}$ & $\begin{array}{l}\text { ar level (20 } \\
\text { es and incl } \\
\text { C) in the } \\
\text { road in } 2 \\
\text { rified villa }\end{array}$ & $\begin{array}{l}\text { 07-2011 } \\
\text { ludes: th } \\
\text { ural por } \\
\text { 001, the } \\
\text { ges, the }\end{array}$ & $\begin{array}{l}\text { lation, the } \\
\text { opulation } \\
\text { are of ag }\end{array}$ & $\begin{array}{l}\text { density, } \\
\text { icultural }\end{array}$ & $\begin{array}{l}\text { ontrol se } \\
\text { the share } \\
\text { ge fores } \\
\text { the share } \\
\text { workers } \\
\text { d effects }\end{array}$ \\
\hline
\end{tabular}

Table A5: Main results with IAP controls

\begin{tabular}{|c|c|c|c|c|c|c|c|c|}
\hline & \multicolumn{4}{|c|}{ Police Attacks on Maoists } & \multicolumn{4}{|c|}{ Maoist Attacks on Police } \\
\hline & (1) & (2) & (3) & (4) & (5) & (6) & (7) & (8) \\
\hline Log(Iron Deposit) x Post & $\begin{array}{c}0.093^{* * * *} \\
(0.028)\end{array}$ & $\begin{array}{c}0.091^{* * *} \\
(0.028)\end{array}$ & $\begin{array}{c}0.092^{* * *} \\
(0.028)\end{array}$ & $\begin{array}{c}0.093^{* * * *} \\
(0.027)\end{array}$ & $\begin{array}{c}0.085^{* * * *} \\
(0.023)\end{array}$ & $\begin{array}{c}0.083^{* * *} \\
(0.023)\end{array}$ & $\begin{array}{c}0.085^{* * *} \\
(0.023)\end{array}$ & $\begin{array}{c}0.083^{* * * *} \\
(0.025)\end{array}$ \\
\hline Log(Bauxite Deposit) x Post & $\begin{array}{c}0.018 \\
(0.043)\end{array}$ & $\begin{array}{c}0.020 \\
(0.044)\end{array}$ & $\begin{array}{c}0.019 \\
(0.043)\end{array}$ & $\begin{array}{c}0.022 \\
(0.043)\end{array}$ & $\begin{array}{l}-0.019 \\
(0.045)\end{array}$ & $\begin{array}{c}-0.022 \\
(0.045)\end{array}$ & $\begin{array}{c}-0.019 \\
(0.045)\end{array}$ & $\begin{array}{c}-0.015 \\
(0.044)\end{array}$ \\
\hline Log(Coal Deposit) x Post & $\begin{array}{c}-0.603^{*} \\
(0.310)\end{array}$ & $\begin{array}{c}-0.608^{*} \\
(0.311)\end{array}$ & $\begin{array}{c}-0.605^{*} \\
(0.310)\end{array}$ & $\begin{array}{c}-0.614^{*} \\
(0.311)\end{array}$ & $\begin{array}{c}-0.325^{*} \\
(0.179)\end{array}$ & $\begin{array}{c}-0.332^{*} \\
(0.179)\end{array}$ & $\begin{array}{l}-0.326^{*} \\
(0.178)\end{array}$ & $\begin{array}{l}-0.332^{*} \\
(0.170)\end{array}$ \\
\hline Mean DV & 0.389 & 0.389 & 0.389 & 0.389 & 0.296 & 0.296 & 0.296 & 0.296 \\
\hline Standard Deviation & 0.687 & 0.687 & 0.687 & 0.687 & 0.602 & 0.602 & 0.602 & 0.602 \\
\hline Observations & 540 & 540 & 540 & 540 & 540 & 540 & 540 & 540 \\
\hline Clusters & 54 & 54 & 54 & 54 & 54 & 54 & 54 & 54 \\
\hline $\begin{array}{l}\text { IAP Controls: } \\
\text { Projects Sanctioned } \times \text { Time FE } \\
\text { Projects Taken Up } \times \text { Time FE } \\
\text { Projects Completed } \times \text { Time FE }\end{array}$ & Yes & Yes & Yes & & Yes & Yes & Yes & \\
\hline Expenditures $\times$ Time FE & & & & Yes & & & & Yes \\
\hline
\end{tabular}

Notes: Regressions at the district-half-year level (2007-2011). Outcomes are subject to an asinh transformation. Deposit values are measured as million tonnes (billion tonnes for coal) per 1000 squared $\mathrm{km}$, and subject to a $\log (x+1)$ transformation. Integrated Action Plan data are based on cumulative performance data for 20112012. IAP variables are expressed per 100,000 of the population and subject to a $\log (x+1)$ transformation. All regressions include district fixed effects, state $\times$ time fixed effects, and mineral $\times$ price interactions. Standard errors are clustered at the district level; ${ }^{* *} p<0.01,{ }^{* *} p<0.05,{ }^{*} p<0.1$. 
Table A6: Main Results with price interaction

\begin{tabular}{|c|c|c|c|c|c|c|}
\hline & \multicolumn{3}{|c|}{ Police Attacks on Maoists } & \multicolumn{3}{|c|}{ Maoist Attacks on Police } \\
\hline & \multirow{2}{*}{$\frac{\text { Dummy }}{(1)}$} & \multicolumn{2}{|c|}{ Asinh } & \multirow{2}{*}{$\frac{\text { Dummy }}{(4)}$} & \multicolumn{2}{|c|}{ Asinh } \\
\hline & & $(2)$ & $(3)$ & & $(5)$ & (6) \\
\hline Log(Iron Deposit) x Post & $\begin{array}{c}0.067^{* * *} \\
(0.017)\end{array}$ & $\begin{array}{c}0.067^{* * *} \\
(0.023)\end{array}$ & $\begin{array}{c}0.073^{* * *} \\
(0.023)\end{array}$ & $\begin{array}{c}0.036^{*} \\
(0.019)\end{array}$ & $\begin{array}{l}0.057^{* *} \\
(0.022)\end{array}$ & $\begin{array}{l}0.055^{* *} \\
(0.023)\end{array}$ \\
\hline Log(Iron Deposit) $x$ Price & $\begin{array}{c}0.002 \\
(0.030)\end{array}$ & $(0.035)$ & $\begin{array}{c}0.003 \\
(0.035)\end{array}$ & $\begin{array}{c}0.029 \\
(0.032)\end{array}$ & $\begin{array}{c}0.018 \\
(0.036)\end{array}$ & $\begin{array}{c}0.021 \\
(0.037)\end{array}$ \\
\hline Log(Iron Deposit) x Price $x$ Post & $\begin{array}{c}0.072 \\
(0.053)\end{array}$ & $\begin{array}{c}0.061 \\
(0.073)\end{array}$ & $\begin{array}{c}0.049 \\
(0.073)\end{array}$ & $\begin{array}{c}-0.052 \\
(0.038)\end{array}$ & $\begin{array}{c}-0.031 \\
(0.042)\end{array}$ & $\begin{array}{l}-0.039 \\
(0.042)\end{array}$ \\
\hline Log(Bauxite Deposit) $x$ Post & & & $\begin{array}{c}0.024 \\
(0.030)\end{array}$ & & & $\begin{array}{l}-0.014 \\
(0.034)\end{array}$ \\
\hline Log(Coal Deposit) x Post & & & $\begin{array}{l}-0.018 \\
(0.042)\end{array}$ & & & $\begin{array}{l}-0.017 \\
(0.027)\end{array}$ \\
\hline Log(Bauxite Deposit) $x$ Price & & & $\begin{array}{l}-0.114 \\
(0.185)\end{array}$ & & & $\begin{array}{l}-0.012 \\
(0.146)\end{array}$ \\
\hline Log(Bauxite Deposit) $x$ Price $x$ Post & & & $\begin{array}{l}-0.072 \\
(0.189)\end{array}$ & & & $\begin{array}{l}-0.072 \\
(0.189)\end{array}$ \\
\hline Log(Coal Deposit) x Price & & & $\begin{array}{c}0.065 \\
(0.079)\end{array}$ & & & $\begin{array}{c}0.064 \\
(0.075)\end{array}$ \\
\hline Log(Coal Deposit $) \times$ Price $x$ Post & & & $\begin{array}{c}0.009 \\
(0.123)\end{array}$ & & & $\begin{array}{l}-0.035 \\
(0.098)\end{array}$ \\
\hline F-test on Post terms for Iron Ore (p-value) & 0.001 & 0.009 & 0.002 & 0.053 & 0.005 & 0.003 \\
\hline Observations & 1440 & 1440 & 1440 & 1440 & 1440 & 1440 \\
\hline Clusters & 144 & 144 & 144 & 144 & 144 & 144 \\
\hline
\end{tabular}

Notes: Regressions at the district-half-year level (2007-2011). Deposit values are measured as million tonnes (billion tonnes for coal) per 1000 squared $\mathrm{km}$, and subject to a $\log (x+1)$ transformation. Price measures are subject to a log transformation and demeaned to facilitate the interpretation of non-interacted terms. All regressions include district fixed effects and state $\times$ time fixed effects. Standard errors are clustered at the district level; ${ }^{* * *} p<0.01,{ }^{* *} p<0.05,{ }^{*} p<0.1$.

Table A7: Main Results with Conley standard errors

\begin{tabular}{|c|c|c|c|c|c|c|}
\hline & \multicolumn{3}{|c|}{ Police Attacks on Maoists } & \multicolumn{3}{|c|}{ Maoist Attacks on Police } \\
\hline & \multirow{2}{*}{$\frac{\text { Dummy }}{(1)}$} & \multicolumn{2}{|c|}{ Asinh } & \multirow{2}{*}{$\frac{\text { Dummy }}{(4)}$} & \multicolumn{2}{|c|}{ Asinh } \\
\hline & & $(2)$ & (3) & & $(5)$ & $(6)$ \\
\hline Log(Iron Deposit) x Post & $\begin{array}{c}0.068^{* * * *} \\
(0.017)\end{array}$ & $\begin{array}{c}0.068^{* * *} \\
(0.022)\end{array}$ & $\begin{array}{c}0.074^{* * *} \\
(0.022)\end{array}$ & $\begin{array}{l}0.035^{* *} \\
(0.017)\end{array}$ & $\begin{array}{c}0.056^{* * *} \\
(0.019)\end{array}$ & $\begin{array}{c}0.054^{* * *} \\
(0.019)\end{array}$ \\
\hline Log(Bauxite Deposit) x Post & & & $\begin{array}{c}0.016 \\
(0.029)\end{array}$ & & & $\begin{array}{l}-0.019 \\
(0.029)\end{array}$ \\
\hline Log(Coal Deposit) x Post & & & $\begin{array}{c}-0.018 \\
(0.036)\end{array}$ & & & $\begin{array}{c}-0.017 \\
(0.021)\end{array}$ \\
\hline Observations & 1440 & 1440 & 1440 & 1440 & 1440 & 1440 \\
\hline
\end{tabular}

Notes: Regressions at the district-half-year level (2007-2011). Deposit values are measured as million tonnes (billion tonnes for coal) per 1000 squared $\mathrm{km}$, and subject to a $\log (x+1)$ transformation. All regressions include district fixed effects, state $\times$ time fixed effects, and mineral $\times$ price interactions. . Standard errors are corrected for geospatial correlation using Conley's method for a 200km cut-off; ${ }^{* *} p<0.01,{ }^{* *} p<0.05,{ }^{*} p<0.1$. 
Table A8: Main Results for per capita violence outcomes

\begin{tabular}{lccccc}
\hline & \multicolumn{2}{l}{ Police Attacks on Maoists } & & \multicolumn{2}{l}{ Maoist Attacks on Police } \\
\cline { 2 - 3 } \cline { 5 - 6 } & $(1)$ & $(2)$ & & $(3)$ & $(4)$ \\
\cline { 2 - 3 } $\log ($ Iron Deposit) x Post & $0.059^{* *}$ & $0.065^{* *}$ & & $0.083^{*}$ & $0.084^{*}$ \\
& $(0.026)$ & $(0.025)$ & & $(0.050)$ & $(0.051)$ \\
Log(Bauxite Deposit) x Post & & -0.016 & & 0.003 \\
& & $(0.057)$ & & $(0.060)$ \\
$\log ($ Coal Deposit) x Post & & -0.010 & & -0.020 \\
& & $(0.041)$ & & $0.027)$ \\
Mean DV & 0.224 & 0.224 & & 0.195 & 0.195 \\
Standard Deviation & 1.215 & 1.215 & & 1.098 & 1.098 \\
Observations & 1440 & 1440 & & 1440 & 1440 \\
Clusters & 144 & 144 & & 144 & 144 \\
\hline
\end{tabular}

Notes: Regressions at the district-half-year level (2007-2011). Deposit values are measured as million tonnes (billion tonnes for coal) per 1000 squared $\mathrm{km}$, and subject to a $\log (x+1)$ transformation. Per capita outcomes are standardized by 1 million of the district level population. We control for mineral prices as in table 2. All regressions include district fixed effects and state $\times$ time fixed effects. Standard errors are clustered at the district level; ${ }^{* *} p<0.01,{ }^{* *} p<0.05,{ }^{*} p<0.1$.

Table A9: Main Results in Poisson Model

\begin{tabular}{lcc}
\hline & $\begin{array}{c}\text { Police Attacks on Maoists } \\
(1)\end{array}$ & $\begin{array}{c}\text { Maoist Attacks on Police } \\
(2)\end{array}$ \\
\cline { 2 - 3 } & $0.254^{*}$ & $0.256^{* * *}$ \\
Log(Iron Deposit) x Post & $(0.136)$ & $(0.087)$ \\
& 0.156 & -0.114 \\
Log(Bauxite Deposit) x Post & $(0.164)$ & $(0.302)$ \\
& 0.117 & -0.212 \\
Log(Coal Deposit) x Post & $(0.532)$ & $(0.504)$ \\
& 0.621 & 0.595 \\
Mean DV & 1.561 & 1.409 \\
Standard Deviation & 628 & 509 \\
Observations & & \\
\hline
\end{tabular}

Notes: Poisson regressions at the district-half-year level (2007-2011). Deposit values are measured as million tonnes (billion tonnes for coal) per 1000 squared $\mathrm{km}$, and subject to a $\log (x+1)$ transformation. All regressions include district fixed effects, state $\times$ time fixed effects, and mineral $\times$ price interactions. Standard errors are clustered at the district level; ${ }^{* *} p<0.01,{ }^{* *} p<0.05,{ }^{*} p<0.1$. 


\section{Table A10: Main Results with dummy mining measures}

\begin{tabular}{|c|c|c|c|c|c|c|}
\hline & \multicolumn{3}{|c|}{ Police Attacks on Maoists } & \multicolumn{3}{|c|}{ Maoist Attacks on Police } \\
\hline & \multirow{2}{*}{$\frac{\text { Dummy }}{(1)}$} & \multicolumn{2}{|c|}{ Asinh } & \multirow{2}{*}{$\frac{\text { Dummy }}{(4)}$} & \multicolumn{2}{|c|}{ Asinh } \\
\hline & & $(2)$ & $(3)$ & & $(5)$ & $(6)$ \\
\hline \multicolumn{7}{|l|}{ Panel A: Dummy mineral measure } \\
\hline Iron Deposit x Post & $\begin{array}{l}0.107^{*} \\
(0.060)\end{array}$ & $\begin{array}{l}0.124^{*} \\
(0.074)\end{array}$ & $\begin{array}{c}0.136^{*} \\
(0.071)\end{array}$ & $\begin{array}{c}0.085 \\
(0.058)\end{array}$ & $\begin{array}{c}0.118 \\
(0.079)\end{array}$ & $\begin{array}{c}0.116 \\
(0.082)\end{array}$ \\
\hline Bauxite Deposit x Post & & & $\begin{array}{c}0.063 \\
(0.086)\end{array}$ & & & $\begin{array}{l}-0.082 \\
(0.092)\end{array}$ \\
\hline Coal Deposit x Post & & & $\begin{array}{l}-0.124 \\
(0.082)\end{array}$ & & & $\begin{array}{l}-0.039 \\
(0.052)\end{array}$ \\
\hline Observations & 1440 & 1440 & 1440 & 1440 & 1440 & 1440 \\
\hline Clusters & 144 & 144 & 144 & 144 & 144 & 144 \\
\hline \multicolumn{7}{|c|}{ Panel B: Dummy mineral measure - removing the smallest deposit } \\
\hline Iron Deposit x Post & $\begin{array}{l}0.131^{* *} \\
(0.059)\end{array}$ & $\begin{array}{c}0.141^{*} \\
(0.073)\end{array}$ & $\begin{array}{l}0.164^{* *} \\
(0.069)\end{array}$ & $\begin{array}{c}0.081 \\
(0.057)\end{array}$ & $\begin{array}{c}0.115 \\
(0.079)\end{array}$ & $\begin{array}{c}0.114 \\
(0.084)\end{array}$ \\
\hline Bauxite Deposit x Post & & & $\begin{array}{c}0.078 \\
(0.083)\end{array}$ & & & $\begin{array}{l}-0.074 \\
(0.095)\end{array}$ \\
\hline Coal Deposit x Post & & & $\begin{array}{l}-0.121 \\
(0.081)\end{array}$ & & & $\begin{array}{l}-0.032 \\
(0.052)\end{array}$ \\
\hline Observations & 1440 & 1440 & 1440 & 1440 & 1440 & 1440 \\
\hline Clusters & 144 & 144 & 144 & 144 & 144 & 144 \\
\hline \multicolumn{7}{|c|}{ Panel C: Dummy mineral measure - above median deposits } \\
\hline Iron Deposit (above median) x Post & $\begin{array}{l}0.174^{* *} \\
(0.075)\end{array}$ & $\begin{array}{l}0.210^{* *} \\
(0.087)\end{array}$ & $\begin{array}{l}0.219^{* *} \\
(0.088)\end{array}$ & $\begin{array}{c}0.092 \\
(0.070)\end{array}$ & $\begin{array}{c}0.128 \\
(0.099)\end{array}$ & $\begin{array}{c}0.115 \\
(0.099)\end{array}$ \\
\hline Bauxite Deposit (above median) x Post & & & $\begin{array}{l}-0.020 \\
(0.116)\end{array}$ & & & $\begin{array}{l}-0.100 \\
(0.120)\end{array}$ \\
\hline Coal Deposit (above median) x Post & & & $\begin{array}{l}-0.013 \\
(0.081)\end{array}$ & & & $\begin{array}{l}-0.022 \\
(0.061)\end{array}$ \\
\hline Observations & 1440 & 1440 & 1440 & 1440 & 1440 & 1440 \\
\hline Clusters & 144 & 144 & 144 & 144 & 144 & 144 \\
\hline
\end{tabular}

Notes: Regressions at the district-half-year level (2007-2011). Deposit values are measured as dummies. All regressions include district fixed effects, state $\times$ time fixed effects, and mineral $\times$ price interactions. Standard errors are clustered at the district level; ${ }^{* * *} p<0.01,{ }^{* *} p<0.05$, * $p<0.1$. 
Table A11: Main Results including manganese and chromite

\begin{tabular}{|c|c|c|c|}
\hline \multicolumn{2}{|c|}{ Police Attacks on Maoists } & \multicolumn{2}{|c|}{ Maoist Attacks on Police } \\
\hline Dummy & Asinh & Dummy & Asinh \\
\hline (1) & $(2)$ & (3) & (4) \\
\hline
\end{tabular}

Panel A: Continuous mineral measures for iron, bauxite, and coal

$\begin{array}{lcccc}\text { Log(Iron Deposit) x Post } & 0.074^{* * *} & 0.080^{* * *} & 0.033 & 0.059^{* *} \\ & (0.021) & (0.028) & (0.021) & (0.026) \\ \log \text { (Bauxite Deposit) x Post } & 0.016 & 0.014 & -0.013 & -0.022 \\ & (0.035) & (0.035) & (0.036) & (0.037) \\ \log \text { (Coal Deposit) x Post } & 0.025 & -0.020 & -0.010 & -0.018 \\ & (0.030) & (0.042) & (0.024) & (0.027) \\ \text { Chromite Deposit x Post } & -0.085 & -0.226 & 0.046 & 0.032 \\ & (0.129) & (0.205) & (0.095) & (0.128) \\ \text { Manganese Deposit x Post } & 0.019 & 0.028 & 0.093 & 0.040 \\ & (0.132) & (0.152) & (0.066) & (0.080) \\ \text { Observations } & 1440 & 1440 & 1440 & 1440 \\ \text { Clusters } & 144 & 144 & 144 & 144\end{array}$

Panel B: dummy mineral measures

\begin{tabular}{lcccc} 
Iron Deposit x Post & $0.099^{*}$ & $0.141^{* *}$ & 0.089 & 0.125 \\
& $(0.058)$ & $(0.068)$ & $(0.057)$ & $(0.086)$ \\
Bauxite Deposit x Post & 0.034 & 0.061 & -0.031 & -0.087 \\
& $(0.086)$ & $(0.085)$ & $(0.069)$ & $(0.091)$ \\
Coal Deposit x Post & -0.057 & -0.120 & -0.023 & -0.035 \\
& $(0.059)$ & $(0.081)$ & $(0.042)$ & $(0.052)$ \\
Chromite Deposit x Post & -0.037 & -0.182 & 0.043 & 0.033 \\
Manganese Deposit x Post & $(0.148)$ & $(0.199)$ & $(0.114)$ & $(0.160)$ \\
& 0.095 & 0.106 & $0.128^{*}$ & 0.105 \\
Observations & $(0.147)$ & $(0.164)$ & $(0.067)$ & $(0.081)$ \\
Clusters & 1440 & 1440 & 1440 & 1440 \\
& 144 & 144 & 144 & 144 \\
\hline
\end{tabular}

Notes: Regressions at the district-half-year level (2007-2011). Deposit values are measured as million tonnes (billion tonnes for coal) per 1000 squared $\mathrm{km}$, and subject to a $\log (x+1)$ transformation. All regressions include district fixed effects, state $\times$ time fixed effects, and mineral $\times$ price interactions. Standard errors are clustered at the district level; ${ }^{* *} p<0.01,{ }^{* *} p<0.05,{ }^{*} p<0.1$. 


\section{Table A12: Alternative transformations of the continuous mineral measure}

\begin{tabular}{|c|c|c|c|c|c|c|}
\hline & \multicolumn{3}{|c|}{ Police Attacks on Maoists } & \multicolumn{3}{|c|}{ Maoist Attacks on Police } \\
\hline & \multirow{2}{*}{$\frac{\text { Dummy }}{(1)}$} & \multicolumn{2}{|c|}{ Asinh } & \multirow{2}{*}{$\frac{\text { Dummy }}{(4)}$} & \multicolumn{2}{|c|}{ Asinh } \\
\hline & & (2) & (3) & & (5) & (6) \\
\hline \multicolumn{7}{|c|}{ Panel A: Main deposit measure, $\log (x+1)$} \\
\hline Log(Iron Deposit) x Post & $\begin{array}{c}0.068^{* * *} \\
(0.018)\end{array}$ & $\begin{array}{c}0.068^{* * *} \\
(0.024)\end{array}$ & $\begin{array}{c}0.074^{* * *} \\
(0.024)\end{array}$ & $\begin{array}{l}0.035^{*} \\
(0.019)\end{array}$ & $\begin{array}{l}0.056^{* *} \\
(0.023)\end{array}$ & $\begin{array}{l}0.054^{* *} \\
(0.023)\end{array}$ \\
\hline Log(Bauxite Deposit) x Post & & & $\begin{array}{c}0.016 \\
(0.034)\end{array}$ & & & $\begin{array}{c}-0.019 \\
(0.036)\end{array}$ \\
\hline Log(Coal Deposit) x Post & & & $\begin{array}{l}-0.018 \\
(0.042)\end{array}$ & & & $\begin{array}{l}-0.017 \\
(0.027)\end{array}$ \\
\hline Observations & 1440 & 1440 & 1440 & 1440 & 1440 & 1440 \\
\hline \multicolumn{7}{|c|}{ Panel B: Deposit measure, $\log \left(x^{*} 1000+1\right)$} \\
\hline Log(Iron Deposit) x Post & $\begin{array}{l}0.017^{* *} \\
(0.007)\end{array}$ & $\begin{array}{l}0.018^{* *} \\
(0.009)\end{array}$ & $\begin{array}{l}0.020^{* *} \\
(0.009)\end{array}$ & $\begin{array}{c}0.010 \\
(0.007)\end{array}$ & $\begin{array}{l}0.015^{*} \\
(0.008)\end{array}$ & $\begin{array}{l}0.014^{*} \\
(0.009)\end{array}$ \\
\hline $\log ($ Bauxite Deposit) $x$ Post & & & $\begin{array}{c}0.008 \\
(0.010)\end{array}$ & & & $\begin{array}{l}-0.008 \\
(0.010)\end{array}$ \\
\hline Log(Coal Deposit) x Post & & & $\begin{array}{l}-0.014 \\
(0.011)\end{array}$ & & & $\begin{array}{l}-0.004 \\
(0.007)\end{array}$ \\
\hline Observations & 1440 & 1440 & 1440 & 1440 & 1440 & 1440 \\
\hline \multicolumn{7}{|c|}{ Panel C: Deposit measure, $\log \left(x^{*} 100+1\right)$} \\
\hline Log(Iron Deposit) x Post & $\begin{array}{c}0.024^{* * *} \\
(0.009)\end{array}$ & $\begin{array}{l}0.024^{* *} \\
(0.012)\end{array}$ & $\begin{array}{l}0.027^{* *} \\
(0.011)\end{array}$ & $\begin{array}{c}0.013 \\
(0.009)\end{array}$ & $\begin{array}{l}0.020^{*} \\
(0.011)\end{array}$ & $\begin{array}{l}0.019^{*} \\
(0.011)\end{array}$ \\
\hline Log(Bauxite Deposit) x Post & & & $\begin{array}{c}0.010 \\
(0.013)\end{array}$ & & & $\begin{array}{l}-0.010 \\
(0.014)\end{array}$ \\
\hline Log(Coal Deposit) x Post & & & $\begin{array}{l}-0.017 \\
(0.015)\end{array}$ & & & $\begin{array}{l}-0.006 \\
(0.009)\end{array}$ \\
\hline Observations & 1440 & 1440 & 1440 & 1440 & 1440 & 1440 \\
\hline \multicolumn{7}{|c|}{ Panel D: Deposit measure, $\log \left(x^{*} 10+1\right)$} \\
\hline Log(Iron Deposit) x Post & $\begin{array}{c}0.037^{* * *} \\
(0.013)\end{array}$ & $\begin{array}{l}0.037^{* *} \\
(0.016)\end{array}$ & $\begin{array}{l}0.041^{* *} \\
(0.016)\end{array}$ & $\begin{array}{c}0.019 \\
(0.012)\end{array}$ & $\begin{array}{l}0.030^{* *} \\
(0.015)\end{array}$ & $\begin{array}{l}0.029^{*} \\
(0.015)\end{array}$ \\
\hline Log(Bauxite Deposit) x Post & & & $\begin{array}{c}0.012 \\
(0.020)\end{array}$ & & & $\begin{array}{l}-0.013 \\
(0.020)\end{array}$ \\
\hline Log(Coal Deposit) x Post & & & $\begin{array}{l}-0.021 \\
(0.024)\end{array}$ & & & $\begin{array}{l}-0.009 \\
(0.015)\end{array}$ \\
\hline Observations & 1440 & 1440 & 1440 & 1440 & 1440 & 1440 \\
\hline \multicolumn{7}{|c|}{ Panel E: Deposit measure, $\log (x / 10+1)$} \\
\hline Log(Iron Deposit) x Post & $\begin{array}{c}0.149^{* * *} \\
(0.032)\end{array}$ & $\begin{array}{c}0.152^{* * *} \\
(0.044)\end{array}$ & $\begin{array}{c}0.161^{* * *} \\
(0.044)\end{array}$ & $\begin{array}{l}0.078^{* *} \\
(0.036)\end{array}$ & $\begin{array}{c}0.122^{* * *} \\
(0.046)\end{array}$ & $\begin{array}{l}0.121^{* *} \\
(0.047)\end{array}$ \\
\hline Log(Bauxite Deposit) x Post & & & $\begin{array}{c}0.029 \\
(0.084)\end{array}$ & & & $\begin{array}{l}-0.052 \\
(0.094)\end{array}$ \\
\hline Log(Coal Deposit) x Post & & & $\begin{array}{l}-0.004 \\
(0.133)\end{array}$ & & & $\begin{array}{l}-0.045 \\
(0.087)\end{array}$ \\
\hline Observations & 1440 & 1440 & 1440 & 1440 & 1440 & 1440 \\
\hline \multicolumn{7}{|c|}{ Panel F: Deposit measure, $\log (x / 100+1)$} \\
\hline Log(Iron Deposit) x Post & $\begin{array}{c}0.425^{* * *} \\
(0.106)\end{array}$ & $\begin{array}{c}0.436^{* * *} \\
(0.139)\end{array}$ & $\begin{array}{c}0.456^{* * *} \\
(0.139)\end{array}$ & $\begin{array}{l}0.236^{* *} \\
(0.109)\end{array}$ & $\begin{array}{l}0.339^{* *} \\
(0.157)\end{array}$ & $\begin{array}{l}0.343^{* *} \\
(0.158)\end{array}$ \\
\hline Log(Bauxite Deposit) x Post & & & $\begin{array}{c}0.055 \\
(0.371)\end{array}$ & & & $\begin{array}{l}-0.238 \\
(0.417)\end{array}$ \\
\hline Log(Coal Deposit) x Post & & & $\begin{array}{c}0.019 \\
(0.934)\end{array}$ & & & $\begin{array}{c}-0.241 \\
(0.589)\end{array}$ \\
\hline Observations & 1440 & 1440 & 1440 & 1440 & 1440 & 1440 \\
\hline \multicolumn{7}{|c|}{ Panel G: Deposit measure, $\log (x / 1000+1)$} \\
\hline Log(Iron Deposit) x Post & $\begin{array}{c}2.278^{* * *} \\
(0.688)\end{array}$ & $\begin{array}{c}2.329^{* * *} \\
(0.864)\end{array}$ & $\begin{array}{c}2.441^{* * *} \\
(0.860)\end{array}$ & $\begin{array}{l}1.265^{*} \\
(0.661)\end{array}$ & $\begin{array}{l}1.741^{*} \\
(0.969)\end{array}$ & $\begin{array}{l}1.783^{*} \\
(0.966)\end{array}$ \\
\hline Log(Bauxite Deposit) x Post & & & $\begin{array}{c}5.515^{* * *} \\
(1.860)\end{array}$ & & & $\begin{array}{c}2.508 \\
(5.105)\end{array}$ \\
\hline Log(Coal Deposit) x Post & & & $\begin{array}{c}0.073 \\
(8.710)\end{array}$ & & & $\begin{array}{l}-2.176 \\
(5.326)\end{array}$ \\
\hline Observations & 1440 & 1440 & 1440 & 1440 & 1440 & 1440 \\
\hline
\end{tabular}

Notes: Regressions at the district-half-year level (2007-2011). In panel A, the deposit values are measured as million tonnes (billion tonnes for coal) per 1000 squared $\mathrm{km}$, and subject to a $\log (x+1)$ transformation. In panels $B-G$, these units are adjusted as indicated in the titles. All regressions include district fixed effects, and state $\times$ time fixed effects. Standard errors are clustered at the district level and presented in parentheses; stars indicate $* * *$ $p<0.01,{ }^{* *} p<0.05, * p<0.1$ 
Table A13: Results shutting down reallocation channels

\begin{tabular}{|c|c|c|c|c|c|c|c|c|c|c|c|c|}
\hline & \multicolumn{6}{|c|}{ Police Attacks on Maoists } & \multicolumn{6}{|c|}{ Maoist Attacks on Police } \\
\hline & \multicolumn{3}{|c|}{ Dummy } & \multicolumn{3}{|c|}{ Asinh } & \multicolumn{3}{|c|}{ Dummy } & \multicolumn{3}{|c|}{ Asinh } \\
\hline & $(1)$ & $(2)$ & (3) & (4) & (5) & (6) & (7) & $(8)$ & (9) & (10) & $(11)$ & $(12)$ \\
\hline Log(Iron Deposit) x Post & $\begin{array}{c}0.068^{* * * *} \\
(0.018)\end{array}$ & $\begin{array}{c}0.077^{* * * *} \\
(0.019)\end{array}$ & $\begin{array}{c}0.076^{* * * *} \\
(0.020)\end{array}$ & $\begin{array}{c}0.068^{* * * *} \\
(0.024)\end{array}$ & $\begin{array}{c}0.078^{* * *} \\
(0.025)\end{array}$ & $\begin{array}{c}0.078^{* * * *} \\
(0.026)\end{array}$ & $\begin{array}{l}0.035^{*} \\
(0.019)\end{array}$ & $\begin{array}{l}0.036^{*} \\
(0.020)\end{array}$ & $\begin{array}{l}0.038^{*} \\
(0.021)\end{array}$ & $\begin{array}{l}0.056^{* *} \\
(0.023)\end{array}$ & $\begin{array}{l}0.059^{* *} \\
(0.024)\end{array}$ & $\begin{array}{l}0.060^{* *} \\
(0.025)\end{array}$ \\
\hline Mean DV & 0.140 & 0.128 & 0.093 & 0.175 & 0.161 & 0.120 & 0.116 & 0.106 & 0.089 & 0.136 & 0.130 & 0.111 \\
\hline Standard Deviation & 0.347 & 0.334 & 0.291 & 0.482 & 0.470 & 0.427 & 0.320 & 0.308 & 0.285 & 0.418 & 0.424 & 0.400 \\
\hline Observations & 1440 & 1050 & 1030 & 1440 & 1050 & 1030 & 1440 & 1050 & 1030 & 1440 & 1050 & 1030 \\
\hline Clusters & 144 & 105 & 103 & 144 & 105 & 103 & 144 & 105 & 103 & 144 & 105 & 103 \\
\hline $\begin{array}{l}\text { Districts dropped } \\
\text { from sample }\end{array}$ & None & $\begin{array}{l}\text { Bordering } \\
\text { iron ore }\end{array}$ & $\begin{array}{l}\text { Containing coal } \\
\text { or bauxite }\end{array}$ & None & $\begin{array}{l}\text { Bordering } \\
\text { iron ore }\end{array}$ & $\begin{array}{c}\text { Containing coal } \\
\text { or bauxite }\end{array}$ & None & $\begin{array}{l}\text { Bordering } \\
\text { iron ore }\end{array}$ & $\begin{array}{l}\text { Containing coal } \\
\text { or bauxite }\end{array}$ & None & $\begin{array}{l}\text { Bordering } \\
\text { iron ore }\end{array}$ & $\begin{array}{l}\text { Containing coal } \\
\text { or bauxite }\end{array}$ \\
\hline
\end{tabular}

Notes: Regressions at the district-half-year level (2007-2011). Deposit values are measured as million tonnes (billion tonnes for coal) per 1000 squared km, and subject to a log(x+1) transformation. The "bordering iron ore" sample includes districts containing iron ore deposits as well as districts bordering those districts. We control for mineral prices as in table 2 . All regressions include district fixed effects and state $\times$ time fixed effects. Standard errors are clustered at the district level; ${ }^{* * *} p<0.01,{ }^{* *} p<0.05,{ }^{*} p<0.1$.

Table A14: Varying time windows

\begin{tabular}{lccccc}
\hline & \multicolumn{5}{c}{ Police Attacks on Maoists } \\
\cline { 2 - 6 } $\log ($ Iron Deposit) x Post & 0.099 & $0.140^{* * *}$ & $0.080^{* *}$ & $0.074^{* * *}$ & $0.068^{* * *}$ \\
& $(0.061)$ & $(0.048)$ & $(0.031)$ & $(0.025)$ & $(0.024)$ \\
Log(Iron Deposit) x Price (real USD per MT) & 0.074 & $0.141^{* * *}$ & $0.059^{*}$ & 0.050 & 0.043 \\
& $(0.070)$ & $(0.054)$ & $(0.035)$ & $(0.034)$ & $(0.034)$ \\
Mean DV & 0.182 & 0.177 & 0.179 & 0.179 & 0.175 \\
Standard Deviation & 0.502 & 0.498 & 0.496 & 0.492 & 0.482 \\
Observations & 576 & 864 & 1152 & 1296 & 1440 \\
Clusters & 144 & 144 & 144 & 144 & 144 \\
Sample & $2008 \mathrm{~h} 1-$ & $2007 \mathrm{~h} 2-$ & $2007 \mathrm{~h} 1-$ & $2007 \mathrm{~h} 1-$ & $2007 \mathrm{~h} 1-$ \\
& $2010 \mathrm{~h} 2$ & $2011 \mathrm{~h} 1$ & $2011 \mathrm{~h} 2$ & $2012 \mathrm{~h} 1$ & $2012 \mathrm{~h} 2$
\end{tabular}

Notes: Regressions at the district-half-year level in the time-windows indicated above. Outcomes are subject to an asinh transformation. Deposit values are measured as million tonnes (billion tonnes for coal) per 1000 squared $\mathrm{km}$, and subject to a $\log (\mathrm{x}+1)$ transformation. The control set includes time-effects for the rural literacy rate, the rural SC/ST population, the percentage forest cover, the percentage of villages connected by road in 2001, and the population density. All regressions include district fixed effects, state $\times$ time fixed effects, and mineral $\times$ price interactions. Standard errors are clustered at the district level; ${ }^{* * *} p<0.01,{ }^{* *} p<0.05,{ }^{*} p<0.1$. 
Table A15: Main Results shifting the treatment to implementation period

\begin{tabular}{|c|c|c|c|c|c|c|}
\hline & \multicolumn{3}{|c|}{ Police Attacks on Maoists } & \multicolumn{3}{|c|}{ Maoist Attacks on Police } \\
\hline & \multirow{2}{*}{$\frac{\text { Dummy }}{(1)}$} & \multicolumn{2}{|c|}{ Asinh } & \multirow{2}{*}{$\frac{\text { Dummy }}{(4)}$} & \multicolumn{2}{|c|}{ Asinh } \\
\hline & & $(2)$ & (3) & & (5) & (6) \\
\hline Log(Iron Deposit) x f.Post & $\begin{array}{c}0.054^{* * *} \\
(0.018)\end{array}$ & $\begin{array}{l}0.051^{* *} \\
(0.025)\end{array}$ & $\begin{array}{l}0.058^{* *} \\
(0.025)\end{array}$ & $\begin{array}{c}0.021 \\
(0.017)\end{array}$ & $\begin{array}{l}0.034^{*} \\
(0.020)\end{array}$ & $\begin{array}{c}0.033 \\
(0.020)\end{array}$ \\
\hline Log(Bauxite Deposit) x f.Post & & & $\begin{array}{l}-0.009 \\
(0.039)\end{array}$ & & & $\begin{array}{l}-0.019 \\
(0.047)\end{array}$ \\
\hline Log(Coal Deposit) x f.Post & & & $\begin{array}{c}0.007 \\
(0.045)\end{array}$ & & & $\begin{array}{l}-0.020 \\
(0.035)\end{array}$ \\
\hline Observations & 1440 & 1440 & 1440 & 1440 & 1440 & 1440 \\
\hline Clusters & 144 & 144 & 144 & 144 & 144 & 144 \\
\hline
\end{tabular}

Notes: Regressions at the district-half-year level (2007-2011). Deposit values are measured as million tonnes (billion tonnes for coal) per 1000 squared $\mathrm{km}$, and subject to a $\log (x+1)$ transformation. We control for mineral prices as in table 2. All regressions include district fixed effects and state $x$ time fixed effects. Standard errors are clustered at the district level; ${ }^{* *} p<0.01,{ }^{* *} p<0.05,{ }^{*} p<0.1$.

\section{Table A16: Main Results in sample for mining results}

\begin{tabular}{|c|c|c|c|}
\hline \multicolumn{2}{|c|}{ Police Attacks on Maoists } & \multicolumn{2}{|c|}{ Maoist Attacks on Police } \\
\hline Dummy & Asinh & Dummy & Asinh \\
\hline (1) & $(2)$ & (3) & $(4)$ \\
\hline
\end{tabular}

Panel A: Districts with Bauxite, Chromite Iron, or Manganese deposits

$\begin{array}{lcccc}\text { Log(Iron Deposit) x Post } & 0.054^{* * *} & 0.049^{* *} & 0.029 & 0.049^{* *} \\ & (0.017) & (0.024) & (0.017) & (0.022) \\ \text { Mean DV } & 0.273 & 0.361 & 0.184 & 0.248 \\ \text { Standard Deviation } & 0.446 & 0.666 & 0.388 & 0.594 \\ \text { Observations } & 450 & 450 & 450 & 450 \\ \text { Clusters } & 45 & 45 & 45 & 45\end{array}$

Panel B: Districts with satellite measures

$\begin{array}{lcccc}\text { Log(Iron Deposit) x Post } & 0.064^{*} & 0.069 & 0.067^{*} & 0.079^{*} \\ & (0.031) & (0.039) & (0.034) & (0.038) \\ \text { Mean DV } & 0.229 & 0.261 & 0.207 & 0.223 \\ \text { Standard Deviation } & 0.421 & 0.508 & 0.407 & 0.469 \\ \text { Observations } & 140 & 140 & 140 & 140 \\ \text { Clusters } & 14 & 14 & 14 & 14\end{array}$

Notes: Regressions at the district-half-year level (2007-2011). Deposit values are measured as million tonnes (billion tonnes for coal) per 1000 squared $\mathrm{km}$, and subject to a $\log (x+1)$ transformation. We control for mineral prices as in table 2 . All regressions include district fixed effects and state $\times$ time fixed effects. Standard errors are clustered at the district level; ${ }^{* *} p<0.01,{ }^{* *} p<0.05,{ }^{*} p<0.1$. 
Table A17: Main Results in restricted samples

\begin{tabular}{|c|c|c|c|c|c|c|}
\hline & \multicolumn{3}{|c|}{ Police Attacks on Maoists } & \multicolumn{3}{|c|}{ Maoist Attacks on Police } \\
\hline & \multirow{2}{*}{$\frac{\text { Dummy }}{(1)}$} & \multicolumn{2}{|c|}{ Asinh } & \multirow{2}{*}{$\frac{\text { Dummy }}{(4)}$} & \multicolumn{2}{|c|}{ Asinh } \\
\hline & & $(2)$ & (3) & & (5) & $(6)$ \\
\hline \multicolumn{7}{|c|}{ Panel A: Dropping Jharkhand } \\
\hline Log(Iron Deposit) x Post & $\begin{array}{c}0.053^{* * *} \\
(0.018)\end{array}$ & $\begin{array}{l}0.050^{* *} \\
(0.025)\end{array}$ & $\begin{array}{l}0.054^{* *} \\
(0.025)\end{array}$ & $\begin{array}{c}0.020 \\
(0.020)\end{array}$ & $\begin{array}{l}0.038^{*} \\
(0.023)\end{array}$ & $\begin{array}{c}0.033 \\
(0.023)\end{array}$ \\
\hline Log(Bauxite Deposit) $x$ Post & & & $\begin{array}{c}0.006 \\
(0.034)\end{array}$ & & & $\begin{array}{l}-0.046 \\
(0.036)\end{array}$ \\
\hline Log(Coal Deposit) x Post & & & $\begin{array}{l}-0.013 \\
(0.045)\end{array}$ & & & $\begin{array}{l}-0.023 \\
(0.025)\end{array}$ \\
\hline Mean DV & 0.121 & 0.152 & 0.152 & 0.092 & 0.114 & 0.114 \\
\hline Standard Deviation & 0.326 & 0.461 & 0.461 & 0.289 & 0.399 & 0.399 \\
\hline Observations & 1260 & 1260 & 1260 & 1260 & 1260 & 1260 \\
\hline Clusters & 126 & 126 & 126 & 126 & 126 & 126 \\
\hline \multicolumn{7}{|c|}{ Panel B: Keeping only districts bordering iron ore districts } \\
\hline Log(Iron Deposit) $x$ Post & $\begin{array}{c}0.065^{* * *} \\
(0.017)\end{array}$ & $\begin{array}{l}0.059^{* *} \\
(0.023)\end{array}$ & $\begin{array}{l}0.052^{* *} \\
(0.025)\end{array}$ & $\begin{array}{c}0.035^{*} \\
(0.018)\end{array}$ & $\begin{array}{l}0.057^{* *} \\
(0.022)\end{array}$ & $\begin{array}{l}0.052^{* *} \\
(0.022)\end{array}$ \\
\hline Log(Bauxite Deposit) $x$ Post & & & $\begin{array}{l}-0.047 \\
(0.036)\end{array}$ & & & $\begin{array}{l}-0.033 \\
(0.045)\end{array}$ \\
\hline Log(Coal Deposit) x Post & & & $\begin{array}{l}-0.127 \\
(0.105)\end{array}$ & & & $\begin{array}{l}-0.032 \\
(0.053)\end{array}$ \\
\hline Mean DV & 0.227 & 0.303 & 0.303 & 0.173 & 0.221 & 0.221 \\
\hline Standard Deviation & 0.419 & 0.632 & 0.632 & 0.379 & 0.544 & 0.544 \\
\hline Observations & 670 & 670 & 670 & 670 & 670 & 670 \\
\hline Clusters & 67 & 67 & 67 & 67 & 67 & 67 \\
\hline
\end{tabular}

Notes: Regressions at the district-half-year level (2007-2011). Deposit values are measured as million tonnes (billion tonnes for coal) per 1000 squared $\mathrm{km}$, and subject to a $\log (x+1)$ transformation. The sample includes districts containing iron ore deposits as well as districts bordering those districts. We control for mineral prices as in table 2. All regressions include district fixed effects and state $\times$ time fixed effects. Standard errors are clustered at the district level; ${ }^{* * *} p<0.01,{ }^{* *} p<0.05,{ }^{*} p<0.1$.

Table A18: Sample of mines with satellite measurements

\begin{tabular}{lcc}
\hline & \multicolumn{2}{c}{ Included in Mine Sample (0-1) } \\
& $(1)$ & $(2)$ \\
\cline { 2 - 3 } Log(mine area) & $0.03372^{* * *}$ & $0.02891^{* * *}$ \\
& $(0.01014)$ & $(0.01049)$ \\
Expiration Year & 0.00001 & -0.00208 \\
& $(0.00021)$ & $(0.00145)$ \\
Mean DV & 0.176 & 0.134 \\
Standard deviation & 0.381 & 0.342 \\
Observations & 466 & 268 \\
Minerals included & All & Iron Ore \\
\hline
\end{tabular}

Notes: Observations at the level of mines included in the India Directory of Mining Leases. The outcome measures if mines are included in our sample with satellite measurements. Control minerals include: bauxite, manganese and chromite. Standard errors are clustered at the mine level, and presented in parentheses; ${ }^{* * *} p<0.01,{ }^{* *} p<0.05,{ }^{*} p<0.1$. 


\section{Table A19: Illegal Mining - imputed measurements}

\begin{tabular}{lc}
\hline & Imputed satellite measurement (0-1) \\
\cline { 2 - 2 } Iron Ore (0-1) & -0.032 \\
& $(0.030)$ \\
Mean DV & 0.435 \\
Standard Deviation & 0.496 \\
Observations & 558 \\
Clusters & 82 \\
\hline
\end{tabular}

Notes: Annual mine-level data between 2007 and 2013. An imputed measurement is equal to 1 in each year for which satellite measurements are missing and we use information from earlier sample years. Minerals include: iron, bauxite, manganese, and chromite. The regression in column (1) includes mineral fixed effects. Robust standard errors in parentheses; ${ }^{* * *} p<0.01,{ }^{* *} p<0.05,{ }^{*} p<0.1$.

Table A20: Illegal Mining - imputed measurements difference-in-difference

\begin{tabular}{lcc}
\hline & \multicolumn{2}{c}{ Imputed satellite measurement (0-1) } \\
\cline { 2 - 3 } Iron Mine x (2009-2011) & -0.069 & $(2)$ \\
& $(0.056)$ & -0.072 \\
Iron Mine x (2012-2013) & -0.058 & $(0.061)$ \\
& $(0.065)$ & -0.021 \\
Iron Mine x (2009-2011) x Expired & & $(0.077)$ \\
& & 0.010 \\
Iron Mine x (2012-2013) x Expired & & $(0.069)$ \\
& & -0.096 \\
Mean DV & 0.435 & $(0.075)$ \\
Standard Deviation & 0.496 & 0.435 \\
Observations & 558 & 0.496 \\
Clusters & 82 & 558 \\
\hline
\end{tabular}

Notes: Annual mine-level data (2007-2013). An imputed measurement is equal to 1 in each year for which information is missing and we use information from earlier sample years. Control minerals include: bauxite, manganese, and chromite. Regressions include mine, state $\times$ time, and (in column 2) expired status $\times$ time fixed effects. Standard errors are clustered at the mine level and presented in parentheses; ${ }^{* * *} p<0.01,{ }^{* *} p<0.05$, * $p<0.1$. 


\section{Table A21: Illegal Mining - balanced samples}

\begin{tabular}{|c|c|c|c|}
\hline & $\begin{array}{l}\text { Excess Mining (0-1) } \\
\text { (1) }\end{array}$ & $\begin{array}{l}\text { Excess Mining (0-1) } \\
50 \% \text { threshold } \\
\text { (2) }\end{array}$ & $\begin{array}{c}\text { Truck Activity (0-1) } \\
\text { (3) }\end{array}$ \\
\hline \multicolumn{4}{|c|}{ Panel A: Two-period Difference-in-difference (2007-2008; 2009-2011) } \\
\hline Iron Mine $x$ Post & $\begin{array}{l}0.112^{*} \\
(0.062)\end{array}$ & $\begin{array}{l}0.127^{*} \\
(0.066)\end{array}$ & $\begin{array}{l}-0.169^{*} \\
(0.098)\end{array}$ \\
\hline Iron Mine $x$ Post $x$ Expired & & & $\begin{array}{c}0.227 \\
(0.146)\end{array}$ \\
\hline Mean DV & 0.273 & 0.227 & 0.708 \\
\hline Standard deviation & 0.447 & 0.420 & 0.456 \\
\hline Observations & 154 & 154 & 154 \\
\hline Clusters & 77 & 77 & 77 \\
\hline \multicolumn{4}{|c|}{ Panel B: Fully balanced imputed sample } \\
\hline Iron Mine x (2009-2011) & $\begin{array}{l}0.137^{*} \\
(0.070)\end{array}$ & $\begin{array}{l}0.135^{* *} \\
(0.067)\end{array}$ & $\begin{array}{l}-0.134 \\
(0.082)\end{array}$ \\
\hline Iron Mine x (2012-2013) & $\begin{array}{l}0.163^{* *} \\
(0.070)\end{array}$ & $\begin{array}{l}0.141^{* *} \\
(0.066)\end{array}$ & $\begin{array}{l}-0.079 \\
(0.127)\end{array}$ \\
\hline Iron Mine x (2009-2011) x Expired & & & $\begin{array}{l}0.205^{*} \\
(0.122)\end{array}$ \\
\hline Iron Mine x (2012-2013) x Expired & & & $\begin{array}{l}-0.059 \\
(0.173)\end{array}$ \\
\hline Mean DV & 0.275 & 0.228 & 0.702 \\
\hline Standard Deviation & 0.447 & 0.420 & 0.458 \\
\hline Observations & 574 & 574 & 574 \\
\hline Clusters & 82 & 82 & 82 \\
\hline
\end{tabular}

Notes: Results for a mine by time period panel (2007-2013). Truck activity and area measurements are based on satellite imagery analysed for the purpose of this study. The India Directory of Mining Leases contains the expiry data and legal maximum area of each mine. The measures are based on comparing satellite information with these administrative records. For these outcomes, we substitute missing observations with the most recent earlier measurement available for each mine. In the 2period sample (Panel A), we use the most recent measurement in the pre-treatment period (before 2009) and the post-treatment period (2009-2011). In the fully balanced sample (panel B), we assign 2008 measurements to 2007 for 16 mines that are first measured in 2008, which makes the panel fully balanced. The excess mining indicator in column (1) is 'one' when the measured area exceeds the legal area, the indicator in column (2) switches on when the measured area exceeds the legal area by more than $50 \%$. Control minerals include: bauxite, manganese and chromite. Regressions include mine, state $\times$ time, and (in column 3 ) expired status $\times$ time fixed effects. Standard errors are clustered at the mine level; ${ }^{* * *} p<0.01,{ }^{* *} p<0.05,{ }^{*} p<0.1$. 


\section{Additional results for "Fiscal Incentives for Conflict: Evi- dence from India's Red Corridor"}

Table B1: Two-by-two comparisons

\begin{tabular}{|c|c|c|c|c|}
\hline & \multicolumn{2}{|c|}{ Police Attacks on Maoists } & \multicolumn{2}{|c|}{ Maoist Attacks on Police } \\
\hline & $\begin{array}{l}\text { Dummy } \\
\text { (1) }\end{array}$ & $\begin{array}{l}\text { Asinh } \\
(2)\end{array}$ & $\begin{array}{l}\text { Dummy } \\
\text { (3) }\end{array}$ & $\begin{array}{l}\text { Asinh } \\
(4)\end{array}$ \\
\hline \multicolumn{5}{|c|}{ Panel A: Main sample } \\
\hline Iron Deposit x Post & $\begin{array}{c}0.005 \\
(0.056)\end{array}$ & $\begin{array}{l}-0.006 \\
(0.075)\end{array}$ & $\begin{array}{c}0.057 \\
(0.046)\end{array}$ & $\begin{array}{c}0.089 \\
(0.067)\end{array}$ \\
\hline Iron Deposits $(0-1)$ & $\begin{array}{c}0.195^{* * *} \\
(0.068)\end{array}$ & $\begin{array}{l}0.323^{* *} \\
(0.126)\end{array}$ & $\begin{array}{c}0.088 \\
(0.064)\end{array}$ & $\begin{array}{c}0.166 \\
(0.112)\end{array}$ \\
\hline Post 2009 & $\begin{array}{c}0.019 \\
(0.019)\end{array}$ & $\begin{array}{c}0.030 \\
(0.026)\end{array}$ & $\begin{array}{c}0.003 \\
(0.016)\end{array}$ & $\begin{array}{c}0.006 \\
(0.017)\end{array}$ \\
\hline Constant & $\begin{array}{c}0.091^{* * * *} \\
(0.018)\end{array}$ & $\begin{array}{c}0.094^{* * *} \\
(0.019)\end{array}$ & $\begin{array}{c}0.091^{* * *} \\
(0.017)\end{array}$ & $\begin{array}{c}0.090^{* * *} \\
(0.018)\end{array}$ \\
\hline $\begin{array}{l}\text { Observations } \\
\text { Clusters }\end{array}$ & $\begin{array}{c}1440 \\
144\end{array}$ & $\begin{array}{c}1440 \\
144\end{array}$ & $\begin{array}{c}1440 \\
144\end{array}$ & $\begin{array}{c}1440 \\
144\end{array}$ \\
\hline \multicolumn{5}{|c|}{ Panel B: Leaving out Andhra Pradesh } \\
\hline Iron Deposit $x$ Post & $\begin{array}{l}0.133^{* *} \\
(0.059)\end{array}$ & $\begin{array}{l}0.179 * * \\
(0.076)\end{array}$ & $\begin{array}{c}0.110 \\
(0.073)\end{array}$ & $\begin{array}{c}0.165 \\
(0.109)\end{array}$ \\
\hline Iron Deposits $(0-1)$ & $\begin{array}{l}0.149^{*} \\
(0.086)\end{array}$ & $\begin{array}{c}0.298 \\
(0.184)\end{array}$ & $\begin{array}{l}0.205^{* *} \\
(0.099)\end{array}$ & $\begin{array}{l}0.344^{*} \\
(0.181)\end{array}$ \\
\hline Post 2009 & $\begin{array}{c}0.028 \\
(0.020)\end{array}$ & $\begin{array}{c}0.043 \\
(0.028)\end{array}$ & $\begin{array}{c}0.010 \\
(0.016)\end{array}$ & $\begin{array}{c}0.014 \\
(0.017)\end{array}$ \\
\hline Constant & $\begin{array}{c}0.085^{* * *} \\
(0.018)\end{array}$ & $\begin{array}{c}0.087^{* * *} \\
(0.019)\end{array}$ & $\begin{array}{c}0.092^{* * *} \\
(0.018)\end{array}$ & $\begin{array}{c}0.091^{* * *} \\
(0.018)\end{array}$ \\
\hline Observations & 1220 & 1220 & 1220 & 1220 \\
\hline Clusters & 122 & 122 & 122 & 122 \\
\hline \multicolumn{5}{|c|}{ Panel C: Dropping districts with small iron ore deposits } \\
\hline Iron Deposit $x$ Post & $\begin{array}{l}0.124^{*} \\
(0.072)\end{array}$ & $\begin{array}{c}0.145 \\
(0.090)\end{array}$ & $\begin{array}{c}0.092 \\
(0.075)\end{array}$ & $\begin{array}{c}0.127 \\
(0.108)\end{array}$ \\
\hline Iron Deposits $(0-1)$ & $\begin{array}{l}0.195^{* *} \\
(0.093)\end{array}$ & $\begin{array}{l}0.371^{*} \\
(0.204)\end{array}$ & $\begin{array}{l}0.231^{* *} \\
(0.110)\end{array}$ & $\begin{array}{l}0.392^{*} \\
(0.203)\end{array}$ \\
\hline Post 2009 & $\begin{array}{c}0.019 \\
(0.019)\end{array}$ & $\begin{array}{c}0.030 \\
(0.026)\end{array}$ & $\begin{array}{c}0.003 \\
(0.016)\end{array}$ & $\begin{array}{c}0.006 \\
(0.017)\end{array}$ \\
\hline Constant & $\begin{array}{c}0.091^{* * *} \\
(0.018)\end{array}$ & $\begin{array}{c}0.094^{* * *} \\
(0.019)\end{array}$ & $\begin{array}{c}0.091^{* * *} \\
(0.017)\end{array}$ & $\begin{array}{c}0.090^{* * * *} \\
(0.018)\end{array}$ \\
\hline Observations & 1300 & 1300 & 1300 & 1300 \\
\hline Clusters & 130 & 130 & 130 & 130 \\
\hline
\end{tabular}

Notes: Regressions at the district-half-year level (2007-2011). Deposit values are measured as million tonnes (billion tonnes for coal) per 1000 squared $\mathrm{km}$, and subject to a $\log (\mathrm{x}+1)$ transformation. Standard errors are clustered at the district level; ${ }^{* * *} p<0.01,{ }^{* *} p<0.05,{ }^{*} p<0.1$. 


\section{Table B2: Main Results in sample of districts with any violence}

\begin{tabular}{|c|c|c|c|c|c|c|}
\hline & \multicolumn{3}{|c|}{ Police Attacks on Maoists } & \multicolumn{3}{|c|}{ Maoist Attacks on Police } \\
\hline & \multirow{2}{*}{$\frac{\text { Dummy }}{(1)}$} & \multicolumn{2}{|c|}{ Asinh } & \multirow{2}{*}{$\frac{\text { Dummy }}{(4)}$} & \multicolumn{2}{|c|}{ Asinh } \\
\hline & & (2) & (3) & & (5) & (6) \\
\hline Log(Iron Deposit) $\times$ Post & $\begin{array}{c}0.079 * * * \\
(0.020)\end{array}$ & $\begin{array}{c}0.079 * * * \\
(0.026)\end{array}$ & $\begin{array}{c}0.097^{* * *} \\
(0.026)\end{array}$ & $\begin{array}{c}0.039 \\
(0.023)\end{array}$ & $\begin{array}{l}0.069^{* *} \\
(0.028)\end{array}$ & $\begin{array}{l}0.067^{* * *} \\
(0.030)\end{array}$ \\
\hline Log(Bauxite Deposit) $x$ Post & & & $\begin{array}{c}0.037 \\
(0.044)\end{array}$ & & & $\begin{array}{l}-0.012 \\
(0.048)\end{array}$ \\
\hline Log(Coal Deposit $) \times$ Post & & & $\begin{array}{l}-0.141 \\
(0.184)\end{array}$ & & & $\begin{array}{l}-0.119 \\
(0.092)\end{array}$ \\
\hline Mean DV & 0.302 & 0.374 & 0.374 & 0.298 & 0.351 & 0.351 \\
\hline Standard Deviation & 0.459 & 0.652 & 0.652 & 0.458 & 0.612 & 0.612 \\
\hline Observations & 640 & 640 & 640 & 560 & 560 & 560 \\
\hline Clusters & 64 & 64 & 64 & 56 & 56 & 56 \\
\hline
\end{tabular}

Notes: Regressions at the district-half-year level (2007-2011). Deposit values are measured as million tonnes (billion tonnes for coal) per 1000 squared $\mathrm{km}$, and subject to a $\log (x+1)$ transformation. The sample includes districts that have at least one strictly positive value of the relevant outcome during the sample period. We control for mineral prices as in table 2. All regressions include district fixed effects and state $\times$ time fixed effects. Standard errors are clustered at the district level; ${ }^{* * *} p<0.01,{ }^{* *} p<0.05,{ }^{*} p<0.1$.

Table B3: Main Results for $\log (\mathrm{x}+1)$ outcomes

\begin{tabular}{lccccc}
\hline & \multicolumn{2}{l}{ Police Attacks on Maoists } & & \multicolumn{2}{l}{ Maoist Attacks on Police } \\
\cline { 2 - 3 } \cline { 5 - 6 } & $(1)$ & $(2)$ & & $(3)$ & $(4)$ \\
\cline { 2 - 3 } & & & & \\
Log(Iron Deposit) x Post & $0.053^{* * *}$ & $0.058^{* * *}$ & & $0.043^{* *}$ & $0.042^{* *}$ \\
& $(0.018)$ & $(0.018)$ & & $(0.018)$ & $(0.018)$ \\
Log(Bauxite Deposit) x Post & & 0.013 & & -0.014 \\
& & $(0.027)$ & & -0.013 \\
Log(Coal Deposit) x Post & & -0.013 & & $(0.021)$ \\
& & $(0.033)$ & & 0.106 \\
Mean DV & 0.136 & 0.136 & & 0.106 & 0.326 \\
Standard Deviation & 0.376 & 0.376 & & 0.326 & 1440 \\
Observations & 1440 & 1440 & & 1440 & 144 \\
Clusters & 144 & 144 & & 144 & \\
\hline
\end{tabular}

Notes: Regressions at the district-half-year level (2007-2011). Deposit values are measured as million tonnes (billion tonnes for coal) per 1000 squared $\mathrm{km}$, and subject to a $\log (x+1)$ transformation. We control for mineral prices as in table 2. All regressions include district fixed effects, and state $\times$ time fixed effects. Standard errors are clustered at the district level; ${ }^{* * *} p<0.01$, ${ }^{* *} p<0.05,{ }^{*} p<0.1$. 
Table B4: Time Patterns for Iron, Bauxite, and Coal

\begin{tabular}{|c|c|c|c|c|}
\hline & \multicolumn{2}{|c|}{ Police Attacks on Maoists (asinh) } & \multicolumn{2}{|c|}{ Maoist Attacks on Police (asinh) } \\
\hline & $(1)$ & $(2)$ & (3) & $(4)$ \\
\hline \multicolumn{5}{|c|}{ Panel A: Time patterns for Iron Ore } \\
\hline Log(iron dep) x 2009-2011 & $0.069^{* * *}$ & $0.063^{* * *}$ & $0.057^{* *}$ & $0.047^{* *}$ \\
\hline Log(iron dep) x 2012-2013 & $\begin{array}{c}0.019 \\
(0.029)\end{array}$ & $\begin{array}{c}0.014 \\
(0.029)\end{array}$ & $\begin{array}{c}0.007 \\
(0.017)\end{array}$ & $\begin{array}{l}-0.003 \\
(0.018)\end{array}$ \\
\hline Observations & 2016 & 1974 & 2016 & 1974 \\
\hline Clusters & 144 & 141 & 144 & 141 \\
\hline \multicolumn{5}{|c|}{ Panel B: Time patterns for Bauxite } \\
\hline $\log ($ baux dep $) \times 2009-2011$ & $\begin{array}{l}-0.007 \\
(0.035)\end{array}$ & $\begin{array}{c}0.006 \\
(0.040)\end{array}$ & $\begin{array}{l}-0.027 \\
(0.034)\end{array}$ & $\begin{array}{l}-0.040 \\
(0.028)\end{array}$ \\
\hline $\log ($ baux dep $) \times 2012-2013$ & $\begin{array}{l}-0.030 \\
(0.049)\end{array}$ & $\begin{array}{l}-0.017 \\
(0.056)\end{array}$ & $\begin{array}{c}-0.001 \\
(0.023)\end{array}$ & $\begin{array}{c}-0.014 \\
(0.022)\end{array}$ \\
\hline Observations & 2016 & 1974 & 2016 & 1974 \\
\hline Clusters & 144 & 141 & 144 & 141 \\
\hline \multicolumn{5}{|c|}{ Panel C: Time patterns for Coal } \\
\hline $\log ($ coal dep $) \times 2009-2011$ & $\begin{array}{c}-0.053 \\
(0.045)\end{array}$ & $\begin{array}{l}-0.059 \\
(0.041)\end{array}$ & $\begin{array}{c}-0.034 \\
(0.030)\end{array}$ & $\begin{array}{l}-0.003 \\
(0.036)\end{array}$ \\
\hline $\log ($ coal dep) x 2012-2013 & $\begin{array}{l}-0.042 \\
(0.043)\end{array}$ & $\begin{array}{l}-0.048 \\
(0.045)\end{array}$ & $\begin{array}{l}-0.021 \\
(0.036)\end{array}$ & $\begin{array}{c}0.010 \\
(0.044)\end{array}$ \\
\hline Mean DV & 0.155 & 0.158 & 0.126 & 0.129 \\
\hline Standard Deviation & 0.455 & 0.459 & 0.404 & 0.408 \\
\hline Observations & 2016 & 1974 & 2016 & 1974 \\
\hline Clusters & 144 & 141 & 144 & 141 \\
\hline Control $\times$ Post & No & Yes & No & Yes \\
\hline
\end{tabular}

Notes: Regressions at the district-half-year level (2007-2013). Outcomes are subject to an asinh transformation. Deposit values are measured as million Tonnes per $1000 \mathrm{~km}^{2}$, and subject to a $\log (x+1)$ transformation. The control set is interacted with post-treatment dummies and includes: the rural literacy rate, the share of scheduled tribe/scheduled caste (ST/SC) in the rural population, the percentage forest cover, the share of villages connected by road in 2001, the population density, the share of the rural population, the share of electrified villages, the share of agricultural workers, and the percentage of drought-prone areas. All regressions include district fixed effects, state $\times$ time fixed effects, and mineral $\times$ price interactions. Standard errors are clustered at the district level; ${ }^{* * *} p<0.01,{ }^{* *} p<0.05,{ }^{*} p<0.1$. 
Figure B1: Distribution of the transformed iron ore deposit measure

Panel A: Main deposit measure, $\log (\mathrm{x}+1)$

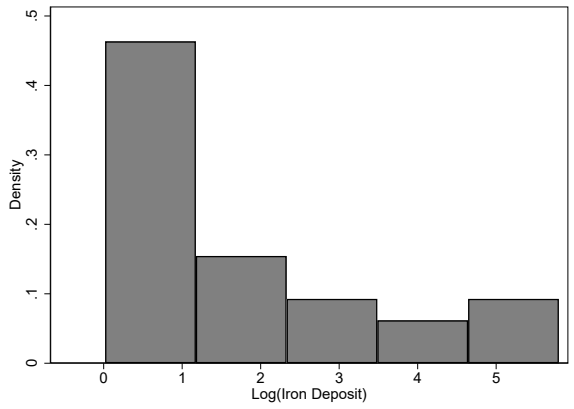

Panel C: Main deposit measure, $\log \left(x^{*} 100+1\right)$

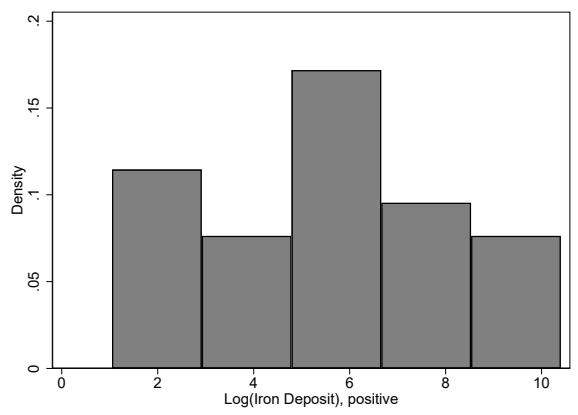

Panel E: Main deposit measure, $\log (\mathrm{x} / 10+1)$

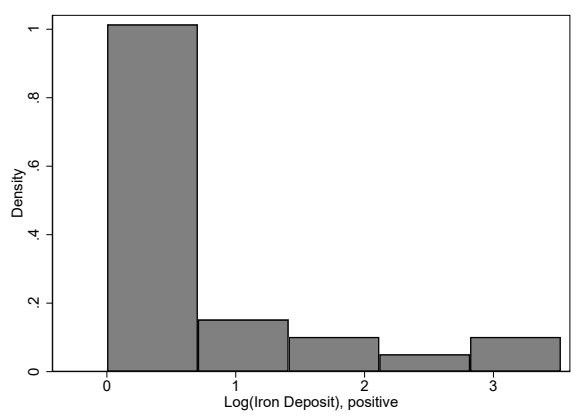

Panel B: Deposit measure, $\log \left(\mathrm{x}^{*} 1000+1\right)$

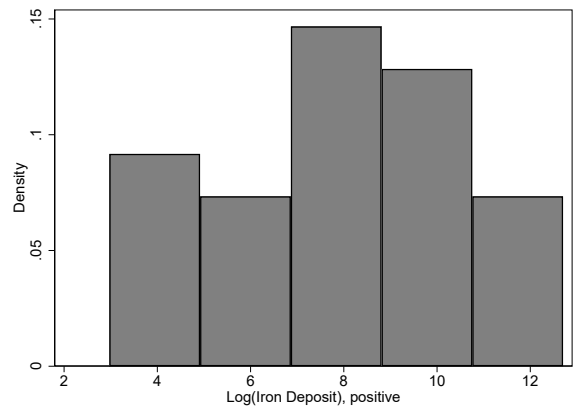

Panel D: Main deposit measure, $\log \left(\mathrm{x}^{*} 10+1\right)$

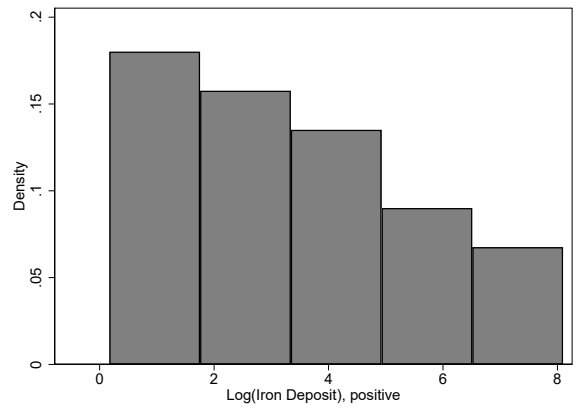

Panel F: Main deposit measure, $\log (\mathrm{x} / 100+1)$

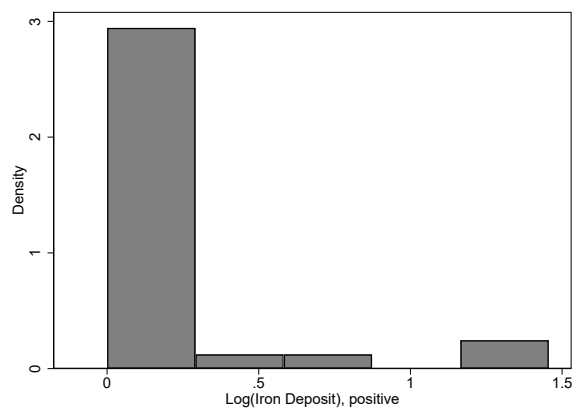

Panel G: Main deposit measure, $\log (\mathrm{x} / 1000+1)$

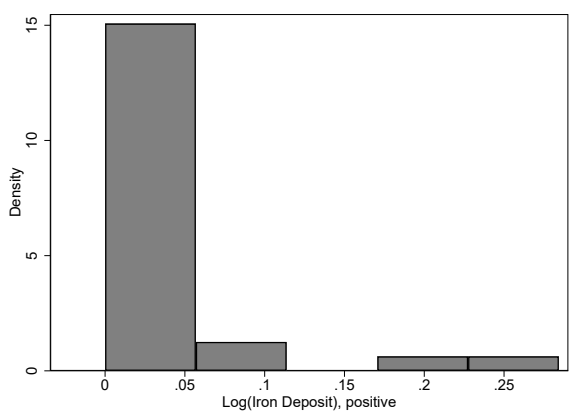

Notes: Iron ore deposit volumes (conditional on strictly positive values), measured at the district level as million tonnes (billion tonnes for coal) per 1000 squared $\mathrm{km}$, and subject to the transformation indicated in the subfigure title. 
Figure B2: Raw time series.

Panel A: Police Attacks on Maoists - dummy Panel B: Maoist Attacks on Police - dummy
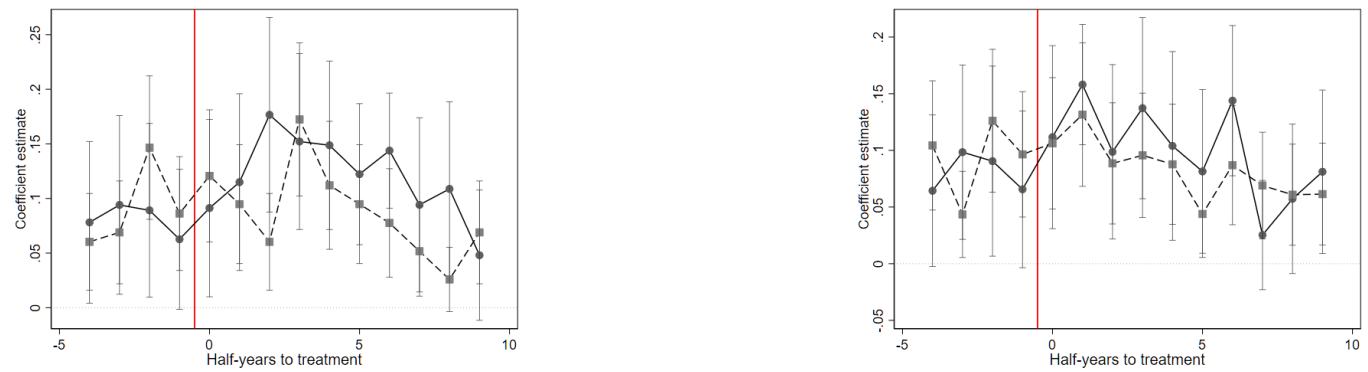

Panel C: Police Attacks on Maoists (asinh)

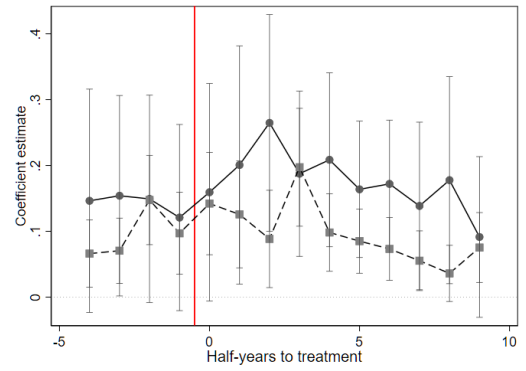

Panel D: Maoist Attacks on Police (asinh)

Panel E: Police Attacks on Maoists
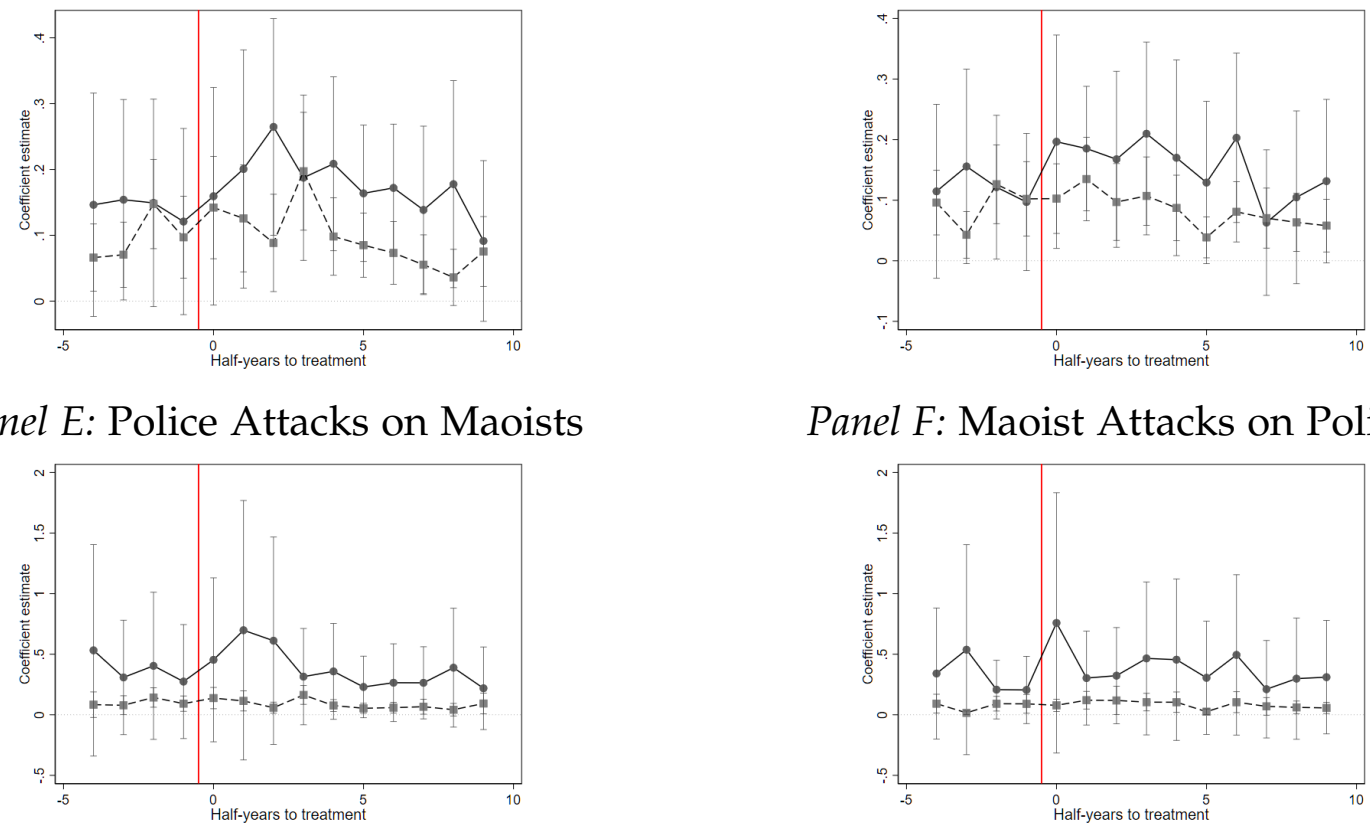

Panel F: Maoist Attacks on Police

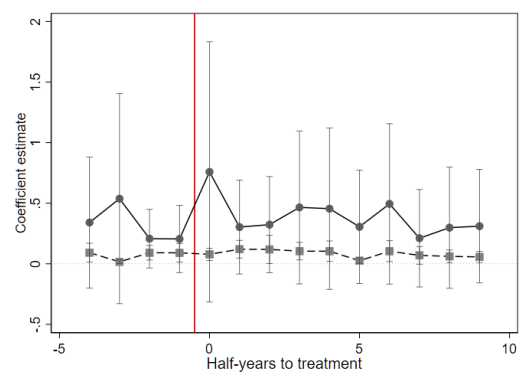

Notes: Half-yearly district-level data between 2007 and 2013. 95\% confidence intervals are shown as grey bars. 